\title{
Trade and Strike Activity in the Postwar United States
}

\author{
M. Rodwan Abouharb 1,*(D) and Benjamin O. Fordham ${ }^{2} \mathbb{D}$ \\ 1 Department of Political Sciences, University College London, London WC1E 6BT, UK \\ 2 Department of Political Science, Binghamton University, Binghamton, NY 13902, USA; \\ bfordham@binghamton.edu \\ * Correspondence: m.abouharb@ucl.ac.uk
}

Received: 3 September 2020; Accepted: 27 October 2020; Published: 31 October 2020

\begin{abstract}
This paper examines the effect of international trade on strike activity within the United States since World War II. Globalization may influence strike activity through its effects on the bargaining position of labor. Alternatively, if labor and management take their changed bargaining positions into account, the rate of change in openness could create greater uncertainty in negotiations between them and lead to more strikes as a result. Empirical analysis of strike activity in the 50 states over this period supports the argument concerning uncertainty in the bargaining process. Import competition may also indirectly reduce strike activity by decreasing union density.
\end{abstract}

Keywords: trade; strikes; work stoppages; United States; union density

What is the effect of trade on strikes? The enormous growth in international trade is one of the most important economic trends of the past forty years. While this increase in the global exchange of goods and services affects the lives of individual people as consumers, it may also influence their working conditions, including the ability to withhold their labor. Strikes are among the most significant forms of social protest that workers can use to maintain and improve their terms and conditions of employment. These conflicts affect the welfare of the workers and viability of the businesses involved. They may also influence broader political outcomes by strengthening or weakening organized labor. The influence of growing exposure to international trade on strike activity is thus one of the most important broader effects of contemporary globalization. Scholars and activists raised concern about globalization's effects on the political influence and economic welfare of labor (e.g., Mosley and Uno 2007; Neumayer and Soysa 2006; Reddy and Barry 2008; Solidarity Center 2007; Tonelson 2002; United Nations 2007; Walker 1999). A number of questions are central to our research. The first is how does trade affect strike activity within the world's largest economy, the United States (International Monetary Fund 2019)? There is little systematic research on this topic. The second and related question is what theoretical framework best explains the how trade impacts strike activity in a relatively labor-scarce country such as the United States?

We present evidence that international trade influences strike activity in the United States, though not in simple and direct ways. Its main effects works through the uncertainty it introduces into bargaining between capital and labor. Trade also indirectly influences strikes through its effect on labor's capacity to organize.

The contribution of our study is threefold. We present the first systematic analysis of the impact of international trade on strike activity at the state level within the United States during the post-World War II period. Our state-level approach allows us to test competing arguments about the linkages between trade and strikes while holding the national context constant. Our approach takes advantage of variation at the sub-national level in export orientation, import competition and strike activity. This level of detail enables us to discriminate with greater confidence among the competing explanations for why trade changes the prevalence of strikes. The second and related contribution is to demonstrate how increased import competition also indirectly affects strike activity through its 
negative consequences on union density, making the organization of strikes more difficult. Our third contribution is the assembly of a comprehensive data set on strike activity at the state level for all 50 states in the U.S. since World War II. We collected it from Bureau of Labor Statistics (BLS) work stoppages data and Freedom of Information Act requests obtaining state strike level data not previously publicly available.

Earlier work examined how economic globalization affects labor unrest at the national level. Some research found that these processes reduced the number of strikes taking place (Piazza 2005), while others have found no discernable effect on union density, thought to be a significant predictor of strikes (Brady 2007; Dreher and Gaston 2007). The existing literature revealed much about how trade liberalization affected labor unrest at the national level, but we believe that there is also much to learn by examining longitudinal cross-sectional data at the sub-national level from within a single country. Cultural and institutional differences, among other potential sources of heterogeneity, are less within a single state than in a cross-national sample. This should give us greater confidence in our inferences about the sources of cross-sectional variation. At the same time, there is substantial cross-sectional variation in exposure to international trade in a large country such as the United States.

This paper follows in five sections. First, we review research on the determinants of strike activity, which includes how trade liberalization affects work stoppages. The second section explains how trade could affect both labor's motives and its means to strike. Although these arguments have generally been tested in cross-national samples, they apply with equal force to cross-sectional variation in strike activity within a single state. Third, we set out a research design for testing hypotheses drawn from our discussion. We use a newly assembled data set on work stoppages and person-days lost to work stoppages covering the 50 American states from 1947 to 1981 and 1984 to 2001. ${ }^{1}$ A fourth section presents our empirical results. A final section summarizes and concludes.

\section{Existing Research Examining Determinants of Strike Activity}

Much of the work which examined strike activity stressed the role of organizing workers, promoting their collective identities (e.g., Jenkins 1983; Polletta and Jasper 2001; Taylor and Whittier 1992) ${ }^{2}$ and mobilizing them in disputes with their employers (McCammon 1994) ${ }^{3}$. Unions can enable workers to demand change in their working conditions through a variety of means, including strikes, because they provide higher levels of resources, strong leadership and the legal framework within which members can make their voices heard (e.g., Ashenfelter and Johnson 1969; Edwards 1996; Kaufman 1982; McCammon 1993; Rubin 1986). Other work examined the impact of collective identity and the idea of solidarity, indicative of class consciousness as a factor promoting mobilization, making strikes more likely (e.g., Godard 1992; Kimeldorf 1999; Roscigno and Danaher 2001).

Some research emphasized the bargaining position of labor as a source of strikes. Research in the United States found that increasingly unionized sectors of the economy are more likely to strike (Cornfield 1991; Wallace et al. 1989). Other work found that repertoires of militant collective action are also more likely when union members have a precarious employment situation (Brueggemann and Boswell 1998; Dubofsky and Tine 1977). These insecure working conditions force unions to become more confrontational, reflecting the established cultural practices and solidarities of workers (Voss 1993). The likelihood of strikes increases when there are both high levels of union density and solidarity amongst members (Dixon et al. 2004; Shorter and Tilly 1974). In a related point, some work argued that previous strike behavior is often a strong predictor of future militancy (Card 1988; Kimeldorf

1 Work stoppages are the technical term used by the Bureau of Labor statistics, including both strikes and work stoppages. Data on work stoppages are available for a longer period of time than we cover in this study. Limitations on key independent variables restrict its scope to the 1947-1981 and 1984-2001 periods.

2 For a good review, see Franzosi (1989).

3 To be sure, other work has argued that union organization may also lower degree of membership activism (e.g., Aronowitz 1973; Brecher 1997; Piven and Cloward 1979). 
1985; Wellman 1995) because past stoppages established organizational and interpersonal networks, which would help facilitate further strikes (Minkoff 1997; Shin 1994). The characteristics of collective bargaining agreements can also change the probability of strikes (Card 1988). Other cross-national research placed an emphasis on political and economic factors and found strikes more common in countries with majoritarian electoral systems (Vernby 2007) and those experiencing high rates of inflation (Kaufman 1981). In comparison, high rates of unemployment (Kaufman 1982) have been linked to fewer strikes, and when the cost of job loss is higher, relative to other sources of income such as social welfare benefits, workers also strike less (Schor and Bowles 1987).

Previous research also considered the effects of trade liberalization on the labor movement. Polanyi (1957) claimed trade had a debilitating effect on workers in the 19th century. Other research spanning both the 19th and 20th centuries provides a more nuanced understanding (Silver 2003). In some cases, trade liberalization has strengthened labor movements in the developing world (Silver 2003) and fostered transnational labor organizing (Kay 2005) while other work has found no discernable impact on unionization (Brady 2007; Dreher and Gaston 2007) or, at best, a marginal effect (Scruggs and Lange 2002). However, trade liberalization may enfeeble labor as governments provide fewer protections for workers (Castells 1997; Mazur 2000; Tilly 1995). As noted, some research found that liberalization lowered the numbers of strikes (Piazza 2005). Unions may acquiesce and not strike in the face of companies threatening to exit and relocate to cheaper locations (Mazur 2000). In contrast, others see unions at the center of a backlash against the consequences of trade liberalization through a resurgent labor movement (Woods et al. 1998) and large-scale protest movements in the Third World (e.g., Walton and Ragin 1990). To be sure, the offshoring process that has taken place in the United States beginning in the 1970s, which saw manufacturing processes moved to Mexico, China, South East Asia and elsewhere, has reduced the numbers of unionized employees. In some cases, multinational corporations establishing new factories in the U.S. then took advantage of right-to-work laws and other mechanisms available to eliminate or reduce the capacity of unions to organize on the shopfloor, making strikes more difficult (Tonelson 2002). A good example is the case of a former General Motors (GM) factory in Dayton, Ohio, that closed in 2008 and then reopened under Chinese ownership as the Fuyao auto glass factory. While the local community welcomed the new jobs to the area hard hit by the financial crisis of 2008, wages for employees were now lower than they had been in the former GM factory and the company's management actively sought to prevent any union organizing on the shop floor (Reichert et al. 2019).

Cross-national studies of the politics of trade implicitly treat countries as homogenous economic entities. This practice masks considerable variation in the impact of trade liberalization within the borders of large countries. In a large country such as the United States, regional differences can be as large as those found in cross-national samples. Labor will face different pressures and opportunities in U.S. states that are dominated by export-oriented industries than it does in states dominated by import-competing sectors. This variation within a single country offers an important advantage for estimating the effect of trade. The cultural and institutional differences between U.S. states are far less than those observed in many cross-national samples. This combination of cross-sectional variation in exposure to international trade and relative homogeneity in other potential influences on strike activity and unionization permits us to test several alternative arguments about the effects of trade on these outcomes. Of course, at the same time, the unusual features of the United States limit the application of our findings to other states. We will return to this issue in the conclusion. We argue that exposure to trade affects the bargaining power of labor and thus its motives to make demands of management, the nature of the bargaining process and the means labor has to engage in collective action.

\section{The Impact of Trade on Strike Activity}

Because international trade can influence the demand for labor, and thus labor's collective bargaining power, it could also affect strike activity. This effect could occur through three distinct but related processes that we outline in this section. The first concerns labor's motives to strike, the second 
concerns the extent of uncertainty in the bargaining process between management and labor and the third concerns labor's ability to organize and, thus, its means of collective action.

Bargaining Power and Motives to Strike. International trade can affect workers' motives to strike by influencing their bargaining power over their employers. Labor has greater bargaining power when demand for it rises. The Stolper-Samuelson theorem (Stolper and Samuelson 1941) holds that increased trade reduces demand for labor and puts downward pressure on real wages in a relatively labor-scarce country such as the United States. The logic of comparative advantage suggests that the country imports more labor-intensive products and focus its productive efforts on goods and services that require less labor. Stolper-Samuelson assumes that capital and labor can move across industrial sectors in response to foreign competition. If factors are immobile across sectors, the negative effects of import competition on wages may be confined to import-competing sectors. Wages might actually rise in export-oriented industries. Both of these approaches have some empirical support in research on the politics of trade (e.g., Scheve and Slaughter 2001; Hiscox 2002; Fordham and McKeown 2003). Overall, the bargaining position of labor should be weakest in relatively import-competing sectors but might be stronger in relatively export-oriented industries. The political effects of trade should differ regionally, depending on the industries that predominate in particular geographic areas.

Our first set of hypotheses comes from the literature emphasizing the impact of labor's bargaining power on strike incidence (e.g., Hahnel 2000). The central claim is that strike activity increases as the bargaining power of labor increases. States with relatively import-sensitive economies should experience less strike activity because international market pressures reduce the bargaining power of labor. For import-sensitive industries, trade liberalization increases pressure to reduce costs and lower wages in order to compete with lower-priced imports (Mazur 2000; Stolper and Samuelson 1941; Tonelson 2002). Labor in these states is essentially competing with lower-paid workers abroad. In this setting, capital should be less likely to make concessions and labor may be reluctant to take action that may result in the loss of jobs. In comparison, relatively export-oriented states should experience more strike activity, as increasing demand for labor strengthens its bargaining position; wages may also increase in export-oriented sectors as the demand for labor rises (Bhagwati 2004). Trade enhances labor's bargaining power and may embolden workers to action for higher wages, greater benefits or improved working conditions. The discussion leads to our first set of hypotheses that we term the 'bargaining power of labor' hypotheses.

Hypothesis 1a (H1a). States with economies that are relatively import-sensitive should experience less strike activity because market pressure reduces the bargaining power of labor.

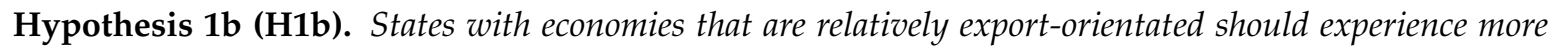
strike activity, as the increasing demand for labor strengthens labor's bargaining position.

Uncertainty in the Bargaining Process. Our second set of hypotheses stems from Tsebelis and Lange (1995), who focus on the bargaining process between management and labor rather than on the relative bargaining power of the two sides. Their argument focuses on considerations that might prevent an efficient strike-avoiding deal between the two sides. Moving beyond the simple claim that increasing labor's bargaining power leads to more strikes, they argue that both management and labor should adjust their demands based on what they know about the relative bargaining power of the other side. When labor is in a strong position, management should make more concessions, avoiding a strike. When labor is in a weaker position, workers should reduce their demands. The relative power of the two sides should thus influence the content of the final bargain but not the probability of a strike. Tsebelis and Lange's game-theoretic model suggests that strikes are most likely when the bargaining power of the two sides are relatively balanced, creating uncertainty about how much each can demand. This uncertainty makes it harder to find an efficient, strike-avoiding bargain. Empirically, they found an inverted U-shaped relationship between union density and strike activity in a sample of developed countries. Strikes were most likely at intermediate levels of unionization rather than 
when labor was either very strong or very weak. Piazza (2005) also found evidence of this non-linear relationship. Other research has also found that imperfect information in the bargaining process increases the numbers of strikes (Cousineau and Lacroix 1986; Gramm 1986; Kaufman 1981; Mauro 1982; Reder and Neumann 1980). Although this effect of union density is not our principal concern here, we will control for it in the empirical analysis that follows.

Tsebelis and Lange focused on union density as a source of uncertainty. Exposure to international markets could have a similar effect by altering the bargaining power of labor and capital in ways that one or the other may not immediately understand. Decision makers on both sides of potential labor disputes often sit atop relatively large organizations, which are not always known for their nimble response to change. In general, larger and more rapid changes in exposure to international markets should create greater uncertainty about relative bargaining power of both sides, making miscalculations and, thus strikes, more likely. Both positive and negative changes in export orientation and import sensitivity could produce uncertainty in this way. ${ }^{4}$ This line of argument leads to our 'trade-related uncertainty' hypothesis:

Hypothesis 2 (H2). Larger absolute changes in import sensitivity and export orientation lead to an increase in strikes.

Unionization and the Means to Strike. Trade liberalization may also undercut workers' means to strike. Trade liberalization weakens unions, making it more difficult for workers to organize themselves (Castells 1997; Mazur 2000; Tilly 1995). Mobilization theories suggest that as organization becomes more difficult, the probability of collective action declines. If exposure to trade weakens unions by reducing their bargaining power, as some have argued (e.g., Tonelson 2002), then it should also have an indirect effect on strike activity by reducing union density. To be sure, it may be that the international competitive pressures that reduce union density depend on whether the industries are export-oriented or import-competing. If so, we expect that only relatively import-sensitive states will experience declining union density. Export orientation should have the opposite effect, strengthening labor's bargaining position and increasing union density. This leads us to our third set of 'union density' hypotheses.

Hypothesis 3a (H3a). States with relatively import-sensitive economies should have lower union density, indirectly reducing the numbers of strikes because market pressure weakens the ability of labor to mobilize.

Hypothesis $3 \mathbf{b} \mathbf{( H 3 b ) . ~ S t a t e s ~ w i t h ~ r e l a t i v e l y ~ e x p o r t - o r i e n t e d ~ e c o n o m i e s ~ s h o u l d ~ h a v e ~ g r e a t e r ~ u n i o n ~ d e n s i t y , ~}$ indirectly increasing the numbers of strikes because market pressure strengthens the ability of labor to mobilize.

\section{Research Design}

Has exposure to international trade really affected strikes in the United States? We estimate the impact of international trade on work stoppages in manufacturing industries, which have produced a substantial share of the tradeable goods as well as being the setting for much of the activities of organized labor. We also examine the impact of exposure to trade on union density because of the possibility that trade liberalization indirectly affects strikes through this intervening variable. Our sample consists of the 50 states during the 1947-1981 and 1984-2001 periods. States differ in many ways that may affect strikes, including, for example: the proportion of the population that are organized into unions, the proportion who are poor or whose incomes are decreasing and whether or not the state has a right-to-work law. In view of these differences, it is not surprising that some previous

4 We will thus sum the absolute change in the value of these two indices to capture trade's effect on uncertainty. This measure assumes that change in exposure to international markets during the past year causes uncertainty. One might argue, instead, for considering change over a longer span of time. As a robustness test, we will use the standard deviation of our two trade measures during the most recent five years. Appendix $C$ presents the results using this index, which are substantively similar to those we found using the one-year changes. 
research on strikes in the United States has examined it at the sub-national level (e.g., Dixon et al. 2004; Ellis 1992; Rosenfeld 2006). To our knowledge, however, none has systematically considered the effect of exposure to trade.

The selection of the 1947-1981 and 1984-2001 periods was dictated by the availability of data. (For some of our models, we have data only back to 1964). Fortunately, this is an informative time in which to consider the effects of trade. Figure 1 shows the role of trade in the American economy since 1929. During the period we will consider, which is shaded in the graph, the American economy moved from a long period of relative autarky to one of much greater trade openness. Trade, as a percentage of gross domestic product (GDP), did not really break out of the low levels seen during the Great Depression until the mid-1960s. Both exports and imports roughly doubled as a percentage of GDP between the mid-1960s and 1980. The period since 1984 has seen further increases in imports, though exports have not risen as quickly. The effects of this trade liberalization process were not uniform across the United States. Differences in its effects across the 50 states as well as over time provide us with considerable explanatory leverage in estimating the impact of trade liberalization on union density and strikes.

Dependent Variables. We examine two dependent variables indicating strike activity in the United States: the annual number of work stoppages that took place in each state and the annual number of person-days lost to work stoppages in each state. These measures provide good indications about the scope and intensity of labor unrest over time. ${ }^{5}$ The BLS defines a work stoppage as a strike or lockout. A strike "is a temporary stoppage of work by a group of workers (not necessarily union members) to express a grievance or enforce a demand. A strike is initiated by the workers of an establishment" (U.S. Department of Labor 2020). A lockout is "a temporary withholding or denial of employment during a labor dispute in order to enforce terms of employment upon a group of employees. A lockout is initiated by the management of an establishment" (U.S. Department of Labor 2020).

We gathered the data used in this project from multiple volumes of the Bureau of Labor Statistics (BLS) Analysis of Work Stoppages publications, as well as several Freedom of Information Act requests to obtain unpublished data from the Federal Mediation and Conciliation Service (FMCS). We used two coders to code data from the BLS volumes and double-check for accuracy, with any remaining cases resolved by the first author. ${ }^{6}$

The Bureau of Labor Statistics, except for the period 1881-1905, does not distinguish between strikes and lockouts. Others note the difficulty in coding these differences when workplace disputes occur (Peterson 1938), with recent calls upon government to monitor and separately document both strikes and lockouts (Van der Velden 2006). Research examines well-known lockouts such as the 130-day lockout at the National Football League, the 161-day lockout at the National Basketball League in 2011 (Staudohar 2012) or the 10-month-and-six-day lockout at the National Baseball league of 2004-2005 (Winfree 2009). However, lockouts are rare in comparison to strikes (Greenhouse 2012). For this reason, the BLS has, for the entire period of our study, gathered data on workplace disputes that it describes as 'work stoppages'.

Between 1947-1981, the BLS collected data on all work stoppages in the United States that involved six workers or more and continued for the equivalent of a full day or shift or longer (U.S. Bureau of Labor Statistics 2019). The BLS used a variety of sources, including newspaper coverage, throughout the country and information from FMCS and state labor-related agencies. These were published annually in the "Analysis of Work Stoppage" bulletins (U.S. Bureau of Labor Statistics 2019). Due to budget reductions, the BLS stopped collecting work stoppage data on all strikes with six or more workers in January 1982 (U.S. Bureau of Labor Statistics 2019).

5 To be sure, our measure cannot capture the extent to which intentionally short but very damaging strikes such as those involved in 'just in time' manufacturing processes take place.

6 Of the 1750 cases coded for the 50 states between 1947 and 1981, only three cases had to be double-checked. 


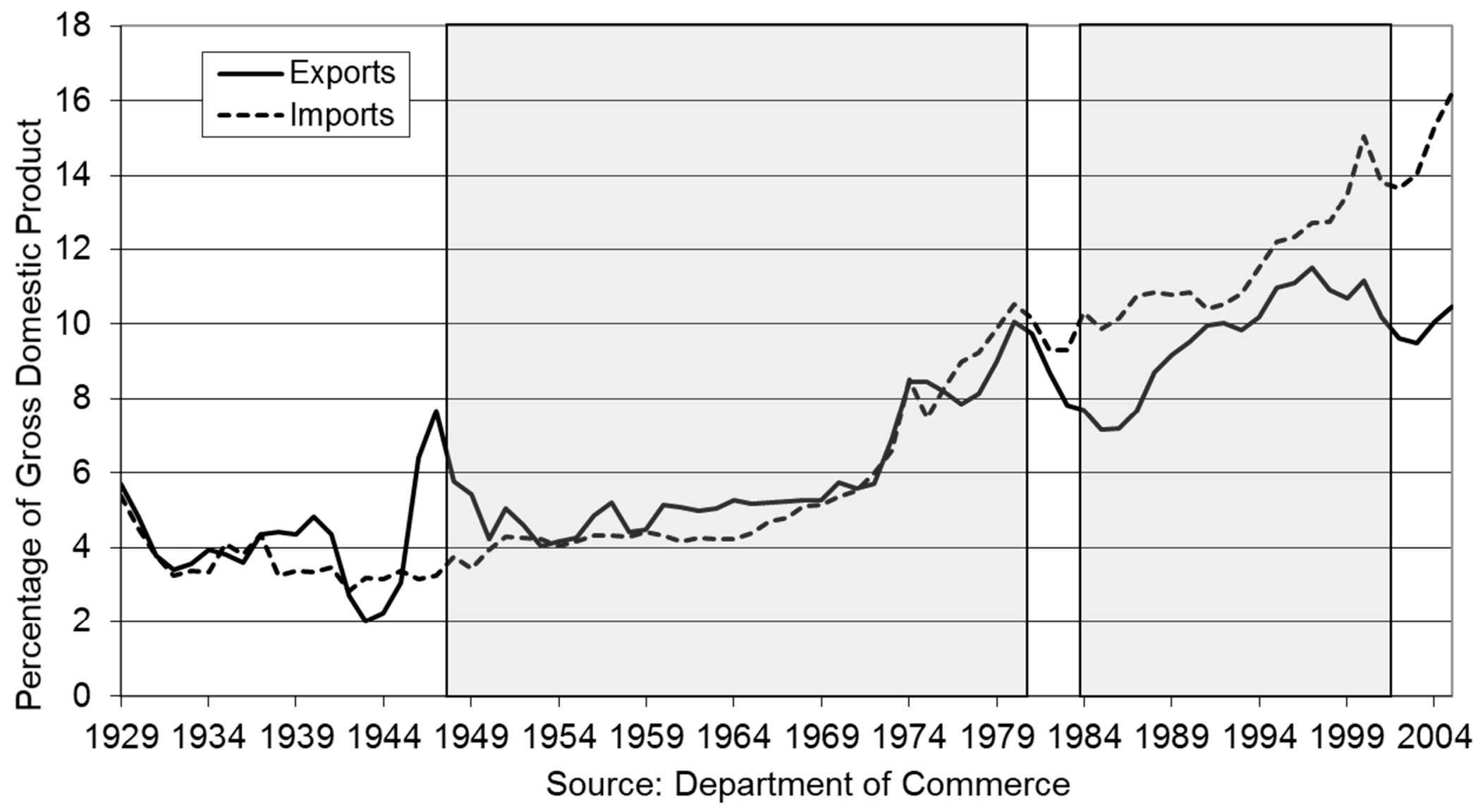

Figure 1. Trade and the American Economy. 
Beginning in 1982, the BLS only collected data on major work stoppages including idling 1000 workers or more for the equivalent of a full day or shift or longer. In addition, between 1982 and 1992, the BLS did not publish state-level work stoppage data. From 1993 onwards, the work stoppage data that were published only provided information about strikes that involved 1000 or more workers. Through Freedom of Information Act requests, we obtained state-level work stoppage data from the FMCS for the 1984-2003 period on almost all work stoppages. The unpublished data from the FMCS cover most of the gaps in the publicly available work stoppage data. The one exception is strikes involving the airline industry which fall under the jurisdiction of the National Mediation Board. Parties unable to resolve contract differences are legally required to file with the FMCS prior to any work stoppage. The data obtained from the FMCS were 'cleaned' to remove any duplicate entries ${ }^{7}$ and aggregated into annual state-level data. To be sure, the FMCS data do not include wildcat strikes, strikes not authorized by the union and strikes over union recognition. There is some indication that wildcat strikes trended downwards from nearly two-thirds of work stoppages in the late 1930s to 13 percent in 1980 (McCammon 1990; Snyder 1977). While it is difficult to estimate the number of wildcat and union recognition strikes excluded from the FMCS sample, we do not believe that it is a very large number for the period under examination.

This process provided us with a dataset that has complete coverage of all 50 states in the United States from 1947-1981 and 1984-2001 for our measure of work stoppages and person-days idle. We were unable to obtain work stoppage data for the years 1982 and 1983. Due to National Archive and Records Administration regulations, the FMCS did not retain records on work stoppages at the state level for the years 1982 and $1983 .^{8}$

There is a clear structural break between the periods before and after the missing years in our dataset. A large and abrupt downward shift is easily visible in the national-level strike data presented in Figure 2. There are a number of reasons to think that the measure for the 1984-2001 period is not comparable to the one from the 1947-1981 period. The FMCS does not count strikes that did not involve it. This means that the coverage of strikes is not as complete in the 1984-2001 period as before. Substantively, the political environment facing the labor movement changed in the 1980s (Rosenfeld 2006). Whatever the reason for the structural break, it implies that we should estimate our model of strike activity separately on the 1947-1981 and 1984-2001 periods. Chow tests on coefficients estimated from the two periods in every model presented here reject the null hypothesis that the relationships remained the same. The independent variables do not have the same effects during the 1947-1981 and 1984-2001 periods.

Primary Independent Variables. Our primary independent variables are indicators of the export-orientation and import-sensitivity of manufacturing industries in each state. Although strikes sometimes occur in other sectors of the economy, the bulk of strikes during the period we examined took place in the manufacturing sector. Feenstra (1996) has compiled national data on manufactured exports and imports by industry groups from 1958 through 1994. These were later updated through 2001 by Peter Schott (Feenstra et al. 2002). We first used these data to estimate the export orientation and import sensitivity of each industry group. For each industry, export orientation is the value of exports divided by the value of total shipments in that sector. Similarly, import sensitivity for each sector is the value of imports of goods it produces divided by total shipments from American producers.

These figures provide us with a good indication of the abundance of opportunities in the international market and the pressure of foreign competition in the domestic market, respectively, facing each industry. For each state, the export orientation or import sensitivity of manufacturing as a whole is the sum of these sectoral measures weighted by each sector's share of personal income from manufacturing in that state in a given year. States in which manufacturing was concentrated in relatively

7 The coding decision to remove duplicate entries was to remove cases where the location, dates of strikes, numbers involved and name of workplace matched. A total of 12 duplicates were found.

8 Letter from the FMCS on file with the author. Available upon request. 
import-sensitive sectors thus received higher import sensitivity scores. States in which manufacturing was concentrated in export-oriented sectors received higher export orientation scores. These scores vary over time either because the composition of manufacturing in a given state changed or because particular industries became more or less export-oriented or import-sensitive. The export orientation index ranges from 0.02 to 0.23 , indicating roughly the proportion of the state's manufacturing output that was exported. The import sensitivity index ranges from 0.01 to 0.37 and indicates imports as a proportion of goods produced in the state's manufacturing sector.

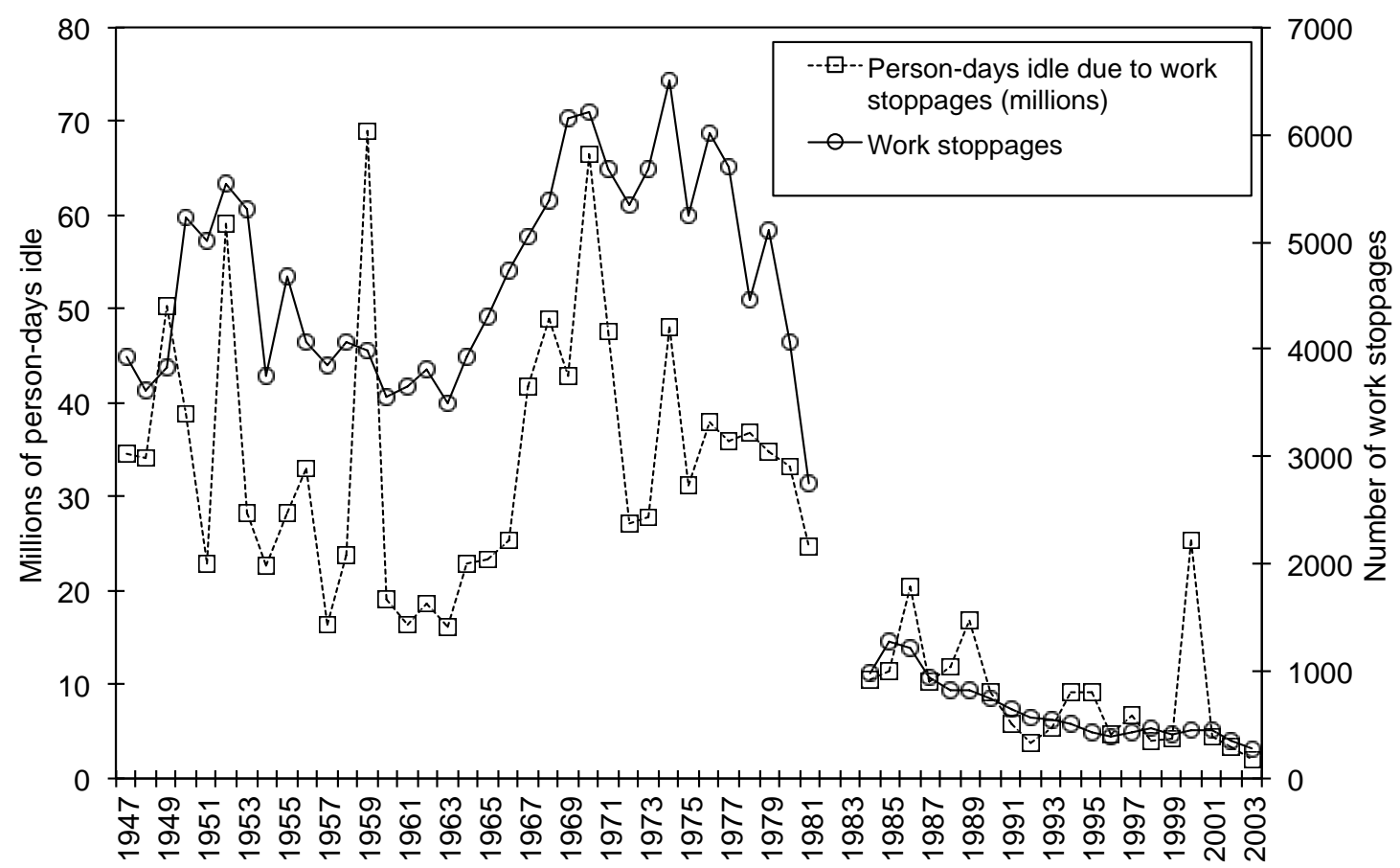

Figure 2. Strike Activity in the United States, 1947-2003.

Our indicator of the uncertainty created by exposure to international trade is derived from our indicators of export orientation and import sensitivity. Change in either of these variables could alter the bargaining power of labor and capital, increasing the chance that one or both sides in negotiations over wages, benefits and working conditions may overestimate their own leverage or underestimate that of their negotiating partner. These miscalculations could lead to work stoppages. Our indicator of uncertainty is the sum of the rate of change in these two variables. Our uncertainty measures ranges from 0.002 to 1.54 , with higher values indicating greater change in exposure to exports and imports.

Control Variables. The models presented below will include several other influences on strike activity and union density. First, states with large populations may have more strikes and experience more person-days idle simply because their work force is larger. Rather than dividing the dependent variables by the size of the workforce in each state, we include the number of wage and salary employees in each state as an independent variable (U.S. Department of Commerce 2008). This permits us to estimate the relationship between the size of the workforce and strike activity rather than imposing one by assumption.

Second, workers who are relatively well-off should be less likely to strike. Most models of strike activity use real wages to indicate this. Because we were able to obtain state-level data on real wages beginning only in 1969, we will use real per capita personal income (U.S. Department of Commerce 2008). To be sure, there are a number of reasons why per capita personal income may change over the period under examination. They will, in part, reflect the anti-poverty programs directed primarily by the federal government during this period. The extent to which these anti-poverty programs raised per 
capita personal income may have reduced people's likelihood to strike. While not as appropriate as real wages, the two variables are correlated at 0.79 and provide us with several years of additional data.

Third, we will include several variables indicating labor market conditions that could affect both strike activity and union density. Union density itself is frequently associated with greater strike activity, since organized workers should find it easier to engage in collective action. However, as we noted earlier, Tsebelis and Lange (1995) and others have argued that strikes are actually more likely at intermediate levels of union density, when the bargaining power of labor and management are uncertain. We will test this hypothesis by including both union density and its square in some specifications. ${ }^{9}$ A high unemployment rate should undermine the bargaining position of labor by putting downward pressure on wages. This should make it more difficult to organize as well as to strike, reducing both strike activity and union density. Right-to-work laws, which forbid contracts requiring workers in covered facilities to join the union, should make it more difficult for labor organizations to overcome the collective action problem. ${ }^{10}$ They should also facilitate the hiring of non-union replacement workers in the event of a strike.

Finally, the political climate in each state may influence both strike activity and trade orientation of manufacturing. Labor organizations' strike decisions could be influenced by their expectations about unfavorable reactions by the public or the state government. This same political climate might influence business decisions about the location of manufacturing facilities. In order to capture the prevailing political ideology in each state, we use the citizen and government ideology scores for each state developed by Berry et al. (1998) and updated by Fording (2020). These scores range from 0 (most conservative) to 100 (most liberal). The government score reflects the extent to which liberals or conservative control the state's executive and legislative institutions. The citizen ideology score reflects public sentiment expressed in elections. Because liberals are generally more sympathetic to labor, we expect more strikes when the public and the state government are more liberal. Appendix A presents descriptive statistics on the variables used in the analysis that follows.

\section{Empirical Results}

Table 1 presents three sets of results of models predicting the annual number of strikes. Because of the structural break in the data, we estimated each model separately on the periods before and after the missing years of 1982 and 1983. The unit-root test for panel data suggested by Levin et al. (2002) turned up no evidence of a trend in either of our dependent variables that would threaten our results. Because the annual number of strikes is a count, we used a time-series cross-sectional negative binomial regression model. The first set of models includes no control variables except the lagged dependent variable and the number of wage and salary employees in the state. The second and third sets of models control for other state characteristics in different ways. The second uses fixed effects for each state. The third includes the control variables discussed earlier. We have greater confidence in results that are consistent across all three specifications.

Table 1. Time-Series Cross-Sectional Count Models of Work Stoppages in U.S. States.

\begin{tabular}{lcccccc}
\hline & \multicolumn{2}{c}{ 1. No Controls } & \multicolumn{2}{c}{ 2. State Fixed Effects } & \multicolumn{2}{c}{ 3. Control Variables } \\
\hline & $\mathbf{1 9 4 7 - 1 9 8 1}$ & $\mathbf{1 9 8 4 - 2 0 0 1}$ & $\mathbf{1 9 4 7 - 1 9 8 1}$ & $\mathbf{1 9 8 4 - 2 0 0 1}$ & $\mathbf{1 9 6 4 - 1 9 8 1}$ & $\mathbf{1 9 8 4 - 2 0 0 1}$ \\
\hline \multirow{2}{*}{ Manufacturing import sensitivity } & 5.09 & $-2.63 *$ & 5.24 & $-2.34 *$ & $-3.24 *$ & -1.89 \\
& $(0.72)$ & $(0.92)$ & $(0.73)$ & $(0.94)$ & $(1.36)$ & $(1.11)$ \\
\hline \multirow{2}{*}{ Manufacturing export orientation } & -6.73 & -10.64 & -6.82 & -10.90 & -4.25 & -9.55 \\
& $(0.89)$ & $(1.10)$ & $(0.89)$ & $(1.11)$ & $(1.22)$ & $(1.20)$ \\
\hline
\end{tabular}

9 Union density data are from Hirsch et al. (2001).

10 Data on right to work laws are from Reed (2003). 
Table 1. Cont.

\begin{tabular}{|c|c|c|c|c|c|c|}
\hline & \multicolumn{2}{|c|}{ 1. No Controls } & \multicolumn{2}{|c|}{ 2. State Fixed Effects } & \multicolumn{2}{|c|}{ 3. Control Variables } \\
\hline & 1947-1981 & 1984-2001 & 1947-1981 & 1984-2001 & 1964-1981 & 1984-2001 \\
\hline Uncertainty from exposure to trade & $\begin{array}{l}0.18^{*} \\
(0.06)\end{array}$ & $\begin{array}{l}0.51^{*} \\
(0.29)\end{array}$ & $\begin{array}{l}0.18^{*} \\
(0.07)\end{array}$ & $\begin{array}{l}0.53^{*} \\
(0.29)\end{array}$ & $\begin{array}{l}0.64^{*} \\
(0.12)\end{array}$ & $\begin{array}{c}0.41 \\
(0.29)\end{array}$ \\
\hline $\begin{array}{l}\text { Union density (percent of } \\
\text { workforce) }\end{array}$ & & & & & $\begin{array}{l}0.05^{*} \\
(0.02)\end{array}$ & $\begin{array}{l}0.10^{*} \\
(0.04)\end{array}$ \\
\hline Union density squared & & & & & $\begin{array}{l}-0.001 * \\
(0.0003)\end{array}$ & $\begin{array}{l}-0.002 * \\
(0.001)\end{array}$ \\
\hline $\begin{array}{l}\text { Real per capita personal income } \\
\text { (thousands of US dollars) }\end{array}$ & & & & & $\begin{array}{c}0.07 \\
(0.02)\end{array}$ & $\begin{array}{l}-0.03 \\
(0.03)\end{array}$ \\
\hline Right-to-work law & & & & & $\begin{array}{l}-0.39^{*} \\
(0.11)\end{array}$ & $\begin{array}{l}-0.30 \\
(0.24)\end{array}$ \\
\hline Unemployment rate & & & & & $\begin{array}{l}-0.02 * \\
(0.01)\end{array}$ & $\begin{array}{l}-0.03 * \\
(0.01)\end{array}$ \\
\hline $\begin{array}{l}\text { Ideological orientation of state } \\
\text { citizens }\end{array}$ & & & & & $\begin{array}{c}0.002 \\
(0.001)\end{array}$ & $\begin{array}{l}-0.005 \\
(0.003)\end{array}$ \\
\hline $\begin{array}{l}\text { Ideological orientation of state } \\
\text { government }\end{array}$ & & & & & $\begin{array}{l}-0.001 \\
(0.001)\end{array}$ & $\begin{array}{c}0.001 \\
(0.001)\end{array}$ \\
\hline $\begin{array}{l}\text { Wage and salary employees } \\
\text { (thousands) }\end{array}$ & $\begin{array}{l}0.06^{*} \\
(0.02)\end{array}$ & $\begin{array}{l}0.13^{*} \\
(0.03)\end{array}$ & $\begin{array}{l}0.04 * \\
(0.02)\end{array}$ & $\begin{array}{l}0.09 * \\
(0.03)\end{array}$ & $\begin{array}{c}0.02 \\
(0.03)\end{array}$ & $\begin{array}{l}0.13^{*} \\
(0.03)\end{array}$ \\
\hline Lagged dependent variable & $\begin{array}{l}0.002 * \\
(0.0001)\end{array}$ & $\begin{array}{l}0.004^{*} \\
(0.001)\end{array}$ & $\begin{array}{c}0.002 * \\
(0.0001)\end{array}$ & $\begin{array}{l}0.003 * \\
(0.001)\end{array}$ & $\begin{array}{c}0.002 * \\
(0.0001)\end{array}$ & $\begin{array}{l}0.004^{*} \\
(0.001)\end{array}$ \\
\hline Constant & $\begin{array}{l}2.39 * \\
(0.06)\end{array}$ & $\begin{array}{l}4.02 * \\
(0.20)\end{array}$ & $\begin{array}{l}2.42 * \\
(0.06)\end{array}$ & $\begin{array}{l}4.22 * \\
(0.20)\end{array}$ & $\begin{array}{l}2.06^{*} \\
(0.30)\end{array}$ & $\begin{array}{l}3.44^{*} \\
(0.59)\end{array}$ \\
\hline Observations & 1676 & 849 & 1676 & 849 & 876 & 849 \\
\hline
\end{tabular}

Note: The dependent variable is the annual number of work stoppages. Models estimated using time-series-cross sectional negative binomial models. Asterisks indicate statistical significance at the $p<0.05$ level in a one-tailed test.

The results offer little support for the hypotheses concerning the effects of export-orientation and import-sensitivity on the incidence of strikes. Import sensitivity is statistically significant and associated with fewer strikes in three of the six models testing its effect. However, in two other models, import-sensitivity appears to be associated with more strikes, not fewer, the reverse of what one would expect based on the declining bargaining power of labor as import-sensitivity increases. Export orientation does not have the predicted positive relationship to the number of strikes in any specification. Indeed, if anything, greater export orientation appears to be associated with fewer strikes. ${ }^{11}$ Such surprising and inconsistent results might stem from bargaining between labor and capital of the sort Tsebelis and Lange consider. The weakened position of labor might lead capital to demand too much, resulting in more strikes, or labor to concede more, resulting in fewer of these conflicts. In any event, the evidence does not support the conclusion that either export orientation or import sensitivity had a direct effect on the incidence of strikes consistent with our argument about bargaining power, either before or after the 1982-1983 structural break. We will return to the possibility that these variables have indirect effects working through their impact on union density later.

By contrast, there is greater support for the Tsebelis and Lange uncertainty hypothesis. Our indicator of trade-related uncertainty, the sum of absolute change in export orientation and import sensitivity, has the predicted effect in five of the six models in Table $1 .{ }^{12}$ This relationship

11 The coefficients for export-orientation would be statistically significant if we had hypothesized that it had a negative relationship to the number of strikes. However, this is not what our argument about the impact of trade on labor's bargaining power suggests. To be clear about our results, we cannot reject the null hypothesis concerning our claims about bargaining power. However, this result does not imply that the null hypothesis is true. It means that the relationship between export orientation and strike activity, if any, must stem from a causal process other than the one we proposed.

12 See Appendix C for results using an alternative indicator of trade-related uncertainty. 
was substantial during the $1947-81$ period. It is statistically significant but much smaller during the 1984-2001 period. The results of models 1 and 2 for this period indicate that a one standard deviation increase in trade-induced uncertainty about the relative bargaining power of capital and labor was associated with roughly two additional strikes annually during this period. Model 3, which includes a battery of control variables, associates a smaller increase of between one and two strikes per year with this change in uncertainty during the 1947-1981 period. Between 1984 and 2001, when export orientation and import sensitivity were less volatile, a one standard deviation increase in uncertainty, while statistically significant in models 1 and 2, was associated with an increase of much less than one strike per year. This small relationship for the 1984-2001 period is not significant when the controls in model 3 are added.

The control variables included in model 3 help put these relationships into perspective. Three effects are especially worth considering because of their size in our results and their role in previous research on strike activity: right to work laws, union density and the unemployment rate. Right-to-work laws had a remarkably large effect on the annual number of strikes during the 1964-1981 period. States with these laws had an average of roughly 35 fewer strikes annually during these years. It was not statistically significant during the 1984-2001 period. The effects of union density and unemployment were smaller and closer to the magnitude of the effects we found for trade-related uncertainty. Union density was statistically significant during both periods. It had the inverted U-shaped relationship to strike activity that Tsebelis and Lange predicted. Most of the time, increases in union density were associated with increasing strike activity. A one standard deviation in this variable over its mean value was associated with roughly four more strikes during the 1964-1981 period and three more during the 1984-2001 period. A one standard deviation increase in unemployment was associated with roughly four fewer strikes during the 1964-1981 period and roughly one fewer during the 1984-2001 period. Overall, these other effects suggest that exposure to international trade had a modest effect on strikes but that this effect was less than some other labor market conditions.

Table 2 presents three comparable sets of results concerning our other dependent variable, the number of days idle due to work stoppages. Unlike the annual number of strikes, the number of days idle is a recording convention rather than a true event count. Although statistics for partial days lost to work stoppages are not recorded, such fractional "counts" are certainly possible in theory. Consequently, we estimated these models using ordinary least squares (OLS) regression with panel-corrected standard errors (Beck and Katz 1995).

The results concerning person-days idle due to work stoppages parallel those concerning the number of strikes. Once again, the level of export orientation and import sensitivity are inconsistent and offer little support for our hypotheses concerning these conditions. We found evidence of the expected relationships in only one instance: the 1947-1981 period in the first set of models. However, this result is not robust to the addition of either fixed effects or control variables. As with the results concerning the annual number of strikes, the coefficient estimates of these variables change enormously across the specifications, often changing signs as well as losing statistical significance.

The results concerning the effects of uncertainty about the relative bargaining power of capital and labor were also very similar to those concerning its effects on the number of strikes. During the 1947-1981 period, these effects were statistically significant and substantively meaningful. A one standard deviation increase in uncertainty was associated with increases of between 100,000 and 153,000 person-days idle due to work stoppages across the three models. This amounts to roughly one-sixth of the average annual number of person-days idle per state. 
Table 2. Ordinary least squares (OLS) Models of Person-Days Lost to Work Stoppages in U.S. States.

\begin{tabular}{|c|c|c|c|c|c|c|}
\hline & \multicolumn{2}{|c|}{ 1. No Controls } & \multicolumn{2}{|c|}{ 2. State Fixed Effects } & \multicolumn{2}{|c|}{ 3. Control Variables } \\
\hline & 1947-1981 & 1984-2001 & 1947-1981 & 1984-2001 & 1964-1981 & 1984-2001 \\
\hline Manufacturing import sensitivity & $\begin{array}{l}-349.65 \\
(2378.31)\end{array}$ & $\begin{array}{l}1144.49 \\
(558.76)\end{array}$ & $\begin{array}{c}5821.82 \\
(4125.58)\end{array}$ & $\begin{array}{c}2643.52 \\
(1085.95)\end{array}$ & $\begin{array}{l}-554.90 \\
(2055.63)\end{array}$ & $\begin{array}{l}1531.43 \\
(599.26)\end{array}$ \\
\hline Manufacturing export orientation & $\begin{array}{c}577.56 \\
(2100.00)\end{array}$ & $\begin{array}{l}-2351.20 \\
(999.17)\end{array}$ & $\begin{array}{l}-6223.53 \\
(4031.84)\end{array}$ & $\begin{array}{l}-3787.97 \\
(1428.80)\end{array}$ & $\begin{array}{c}2708.71 \\
(2016.94)\end{array}$ & $\begin{array}{l}-1931.94 \\
(1011.13)\end{array}$ \\
\hline Uncertainty from exposure to trade & $\begin{array}{l}910.54 * \\
(349.47)\end{array}$ & $\begin{array}{c}466.01 \\
(295.85)\end{array}$ & $\begin{array}{l}975.02 * \\
(331.73)\end{array}$ & $\begin{array}{l}484.87 * \\
(286.74)\end{array}$ & $\begin{array}{l}1903.82 * \\
(469.38)\end{array}$ & $\begin{array}{c}322.19 \\
(298.70)\end{array}$ \\
\hline $\begin{array}{l}\text { Union density (percent of } \\
\text { workforce) }\end{array}$ & & & & & $\begin{array}{c}16.11 \\
(21.62)\end{array}$ & $\begin{array}{c}0.35 \\
(40.02)\end{array}$ \\
\hline Union density squared & & & & & $\begin{array}{c}0.31 \\
(0.49)\end{array}$ & $\begin{array}{c}0.84 \\
(1.55)\end{array}$ \\
\hline $\begin{array}{l}\text { Real per capita personal income } \\
\text { (thousands of US dollars) }\end{array}$ & & & & & $\begin{array}{l}-45.36 * \\
(15.59)\end{array}$ & $\begin{array}{c}-1.71 \\
(10.09)\end{array}$ \\
\hline Right-to-work law & & & & & $\begin{array}{l}-93.65 * \\
(37.00)\end{array}$ & $\begin{array}{c}15.11 \\
(41.96)\end{array}$ \\
\hline Unemployment rate & & & & & $\begin{array}{l}-24.72 \\
(23.38)\end{array}$ & $\begin{array}{l}-15.89 \\
(17.23)\end{array}$ \\
\hline $\begin{array}{l}\text { Ideological orientation of state } \\
\text { citizens }\end{array}$ & & & & & $\begin{array}{c}1.44 \\
(2.47)\end{array}$ & $\begin{array}{l}-0.53 \\
(1.24)\end{array}$ \\
\hline $\begin{array}{l}\text { Ideological orientation of state } \\
\text { government }\end{array}$ & & & & & $\begin{array}{l}-4.72 \\
(1.72)\end{array}$ & $\begin{array}{l}-1.20 \\
(0.97)\end{array}$ \\
\hline $\begin{array}{l}\text { Wage and salary employees } \\
\text { (thousands) }\end{array}$ & $\begin{array}{l}0.28 * \\
(0.04)\end{array}$ & $\begin{array}{l}0.08 * \\
(0.02)\end{array}$ & $\begin{array}{c}0.18 \\
(0.13)\end{array}$ & $\begin{array}{l}-0.03 \\
(0.10)\end{array}$ & $\begin{array}{l}0.25 * \\
(0.05)\end{array}$ & $\begin{array}{l}0.06 * \\
(0.02)\end{array}$ \\
\hline Lagged dependent variable & $\begin{array}{l}0.32 * \\
(0.09)\end{array}$ & $\begin{array}{c}0.07 \\
(0.19)\end{array}$ & $\begin{array}{c}0.05 \\
(0.09)\end{array}$ & $\begin{array}{l}-0.05 \\
(0.19)\end{array}$ & $\begin{array}{l}0.33 * \\
(0.10)\end{array}$ & $\begin{array}{c}0.03 \\
(0.19)\end{array}$ \\
\hline Constant & $\begin{array}{l}-162.94 \\
(124.88)\end{array}$ & $\begin{array}{c}22.13 \\
(79.78)\end{array}$ & $\begin{array}{c}247.54 \\
(213.26)\end{array}$ & $\begin{array}{c}240.99 \\
(168.87)\end{array}$ & $\begin{array}{l}-148.18 \\
(281.77)\end{array}$ & $\begin{array}{c}-68.78 \\
(334.56)\end{array}$ \\
\hline R-squared & 0.48 & 0.07 & 0.58 & 0.18 & 0.63 & 0.10 \\
\hline Observations & 1674 & 849 & 1674 & 849 & 876 & 849 \\
\hline
\end{tabular}

Note: The dependent variable is the annual number person-days idle due to work stoppages, in thousands. Panel-corrected standard errors are reported in parentheses. Asterisks indicate statistical significance at the $p<0.05$ level in a one-tailed test.

The control variables included in the third set of models are, again, helpful in assessing the relative importance of uncertainty on strike activity. Union density was arguably the most influential independent variable in this case and the only one statistically significant in both time periods. As the positive coefficients on union density and its square indicate, the inverted U-shaped relationship between union density and strike activity did not hold. However, a simple positive relationship does. (This result is not presented in Table 2 for reasons of space and comparability with Table 1 ). Between 1964 and 1981, a one standard deviation increase in union density was associated with roughly 267,000 additional person-days idle due to work stoppages. Between 1984 and 2001, a one standard deviation increase in union density was associated with roughly 168,000 additional person-days idle. Right-to-work laws and real per capita personal income had somewhat smaller effects during this period. States with right-to-work laws lost roughly 90,000 fewer person-days to work stoppages than states without such laws. As with the models of the number of work stoppages presented in Table 1, the overall picture these results present is one in which the uncertainty-producing effects of trade made a difference, though not one larger than other labor market conditions, such as union density. ${ }^{13}$

13 Appendix B presents two robustness tests arising from possible objections to our dependent variables. Neither substantially changes our results. 
Trade and Union Density. The substantial effect of union density on both the number of work stoppages and the number of person-days idle suggests an additional way that exposure to international trade might influence strike activity. Trade may affect union density and thus have an additional indirect effect on strike activity. Piazza (2005, p. 296) argues that exposure to import competition may diminish the value of unions to workers because the unions' bargaining power is less. Conversely, it is possible that export-orientation could increase the value of unions by increasing their bargaining power. The experience of three states over the postwar era suggests how this indirect effect of trade on strikes through union density might look. Figure 3 plots the increase in import competition and the declining union density in Michigan, New York and North Carolina. The two heavily unionized Northern states both experienced substantial drops in union density as import competition increased. As North Carolina suggests, their experience is not universal but it is typical of the older manufacturing regions of the country. Declining union density could have lasting effects, reducing strikes even after labor and management adapt their bargaining demands to consider increased exposure to international trade.

To test for this effect, we estimated several models of union density in Table 3 using OLS regression with panel-corrected standard errors, as well as a lagged dependent variable to capture time dependence. As with the results presented in Tables 1 and 2, the first set of models contains only the main variables of interest, the second set includes fixed effects for each state and the third includes a battery of control variables representing other influences on union density. Two of the three models in Table 3 contain evidence that import sensitivity was associated with lower union density. There is no evidence that the increasing export orientation that also comes with trade liberalization offsets this effect. A one standard deviation increase in import-competition would decrease union density by roughly 0.2 percent in the fixed-effects model and 0.6 percent in the model with control variables. If import sensitivity rises steadily, as it has during the last 30 years, the decline in union density could be substantial.

Table 3. OLS Models of Union Density in U.S. States, 1964-2001.

\begin{tabular}{|c|c|c|c|}
\hline & 1. No Controls & 2. State Fixed Effects & 3. Control Variables \\
\hline Manufacturing import sensitivity & $\begin{array}{l}-2.30 \\
(1.81)\end{array}$ & $\begin{array}{l}-9.38 * \\
(2.63)\end{array}$ & $\begin{array}{l}-3.33^{*} \\
(1.76)\end{array}$ \\
\hline Manufacturing export orientation & $\begin{array}{c}0.72 \\
(2.90)\end{array}$ & $\begin{array}{l}-0.21 \\
(4.44)\end{array}$ & $\begin{array}{c}0.81 \\
(2.95)\end{array}$ \\
\hline $\begin{array}{l}\text { Percentage of state workforce in } \\
\text { manufacturing }\end{array}$ & & & $\begin{array}{c}0.01 \\
(0.01)\end{array}$ \\
\hline Right-to-work law & & & $\begin{array}{l}-0.28 * \\
(0.10)\end{array}$ \\
\hline Unemployment rate & & & $\begin{array}{c}-0.08 * \\
(0.03)\end{array}$ \\
\hline Ideological orientation of state citizens & & & $\begin{array}{c}0.004 \\
(0.004)\end{array}$ \\
\hline $\begin{array}{l}\text { Ideological orientation of state } \\
\text { government }\end{array}$ & & & $\begin{array}{c}0.001 \\
(0.002)\end{array}$ \\
\hline Lagged dependent variable & $\begin{array}{l}0.97 * \\
(0.01)\end{array}$ & $\begin{array}{l}0.85 * \\
(0.02)\end{array}$ & $\begin{array}{l}0.95 * \\
(0.01)\end{array}$ \\
\hline Constant & $\begin{array}{l}0.49 * \\
(0.18)\end{array}$ & $\begin{array}{l}4.17^{*} \\
(0.80)\end{array}$ & $\begin{array}{l}1.17^{*} \\
(0.33)\end{array}$ \\
\hline R-squared & 0.97 & 0.97 & 0.97 \\
\hline Observations & 1849 & 1849 & 1827 \\
\hline
\end{tabular}

Note: The dependent variable is union membership as a percentage of the workforce. Panel-corrected standard errors are reported in parentheses. Asterisks indicate statistical significance at the $p<0.05$ level in a one-tailed test. 


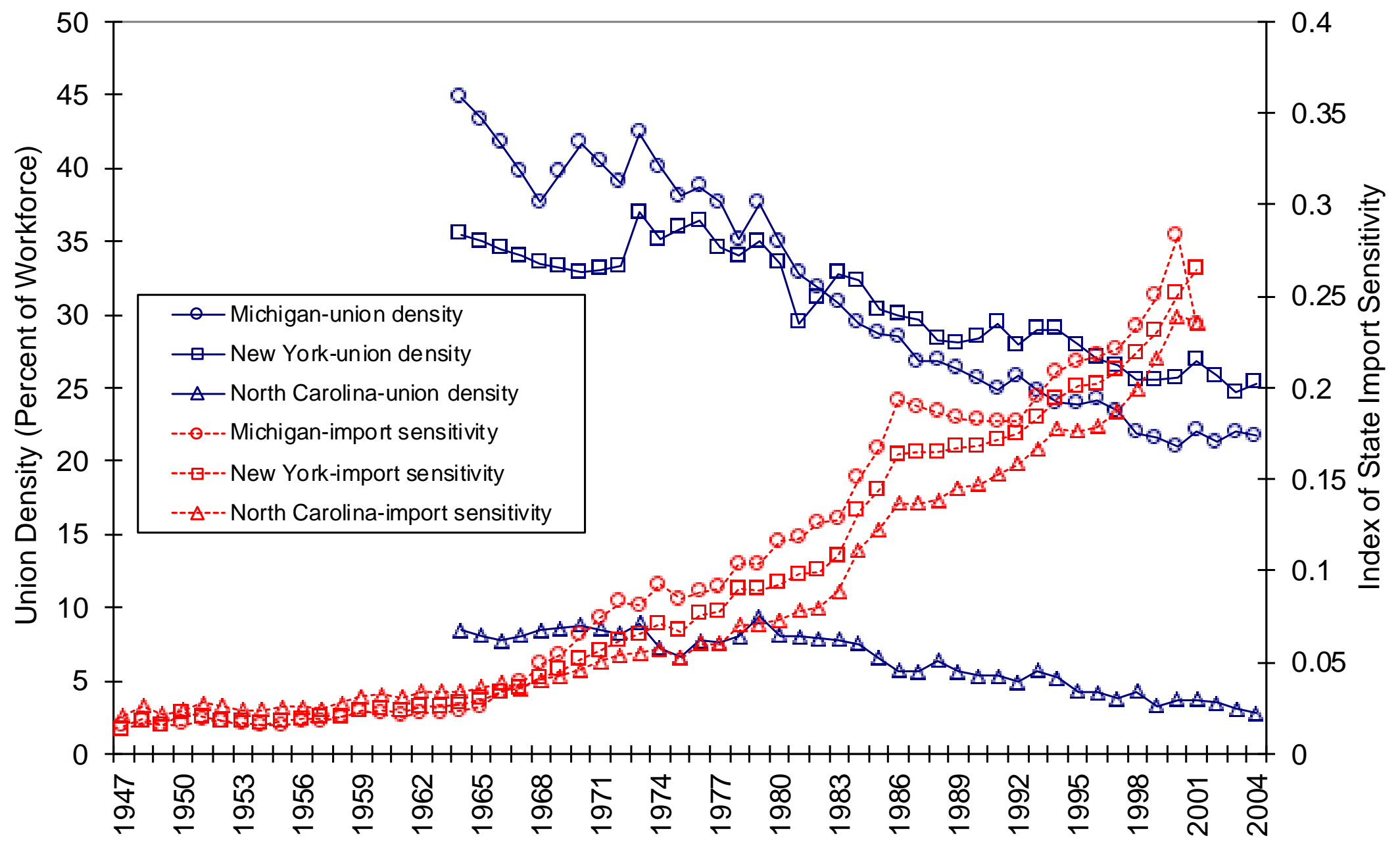

Figure 3. Union Density and Import Competition in Three States, 1947-2004. 
Levin-Lin-Chu test for stationarity of union density panel:

Null hypothesis is that the data are not stationary

5 lags: $-0.46^{*}$

8 lags: $-0.47^{*}$

10 lags: -0.50

15 lags: -0.51

Figure 3 also suggests a potential problem with the models in Table 3 . If every state's union density series were as clearly non-stationary as the series in Figure 3, the results concerning the estimated relationship between union density and import sensitivity might well be spurious. As the North Carolina case in Figure 3 indicates, however, union density in every state did not contain an obvious trend. The statistics reported at the foot of Table 3 test whether the union density panels contain a unit root using the method recommended by Levin et al. (2002). Their approach is similar to an augmented Dickey-Fuller test. The null hypothesis is that the panel data are non-stationary. As the number of lags used in the test increases, the amount of data available for estimating the test statistic declines and the power of the test decreases. Nevertheless, the test statistics that employ 10 and 15 lags still leave a substantial amount of data for estimation since each series is 41 years long. Although the results do not conclusively show that the union density panel is non-stationary, there is clearly cause for concern about the validity of the results in Table 3 .

One way to handle the problem of non-stationarity is to difference the dependent variable. The models in Table 4 adopt this approach, again presenting results with no other independent variables, state fixed effects and a battery of controls. The dependent variable in these models is the change in union density. The independent variables have been differenced as well. If import sensitivity indeed reduces union density, then increasing import sensitivity should be negatively associated with the change in union density. As the results indicate, there is evidence that this is indeed the case. In this case, all three specifications point to roughly the same relationship between the change in union density and the change in import sensitivity. When the change in import sensitivity was one standard deviation above its mean, the annual change in unionization would decline by roughly an additional 0.01 . This is a very small effect for a single year, but sustained increases in import sensitivity over several decades could produce a substantial decline in union density such as the pattern in Figure 3.

Table 4. Differenced OLS Models of the Union Density in U.S. States, 1964-2001.

\begin{tabular}{|c|c|c|c|}
\hline & 1. No Controls & 2. State Fixed Effects & 3. Control Variables \\
\hline Change in manufacturing import sensitivity & $\begin{array}{l}-0.76 * \\
(0.41)\end{array}$ & $\begin{array}{l}-0.79 * \\
(0.41)\end{array}$ & $\begin{array}{l}-0.79 * \\
(0.41)\end{array}$ \\
\hline Change in manufacturing export orientation & $\begin{array}{c}0.47 \\
(0.47)\end{array}$ & $\begin{array}{c}0.47 \\
(0.48)\end{array}$ & $\begin{array}{c}0.53 \\
(0.48)\end{array}$ \\
\hline $\begin{array}{c}\text { Change in percentage of state workforce in } \\
\text { manufacturing }\end{array}$ & & & $\begin{array}{c}0.002 \\
(0.005)\end{array}$ \\
\hline Change in right-to-work law & & & $\begin{array}{c}0.12 \\
(0.07)\end{array}$ \\
\hline Change in unemployment rate & & & $\begin{array}{l}-0.001 \\
(0.003)\end{array}$ \\
\hline $\begin{array}{c}\text { Change in ideological orientation of state } \\
\text { citizens }\end{array}$ & & & $\begin{array}{l}-0.0001 \\
(0.0005)\end{array}$ \\
\hline $\begin{array}{c}\text { Change in ideological orientation of state } \\
\text { government }\end{array}$ & & & $\begin{array}{c}0.0000 \\
(0.0002)\end{array}$ \\
\hline Lagged dependent variable & $\begin{array}{l}-0.18 * \\
(0.05)\end{array}$ & $\begin{array}{l}-0.18 * \\
(0.05)\end{array}$ & $\begin{array}{l}-0.18 * \\
(0.06)\end{array}$ \\
\hline
\end{tabular}


Table 4. Cont.

\begin{tabular}{cccc}
\hline & 1. No Controls & 2. State Fixed Effects & 3. Control Variables \\
\hline Constant & $-0.02 *$ & -0.01 & $-0.02 *$ \\
$(0.01)$ & $0.01)$ & 0.04 \\
\hline R-squared & $(0.004)$ & 0.04 & 1799 \\
\hline Observations & 1799 & 1777 \\
\hline
\end{tabular}

Note: The dependent variable is the change in union membership as a percentage of the workforce. Panel-corrected standard errors are reported in parentheses. Asterisks indicate statistical significance at the $p<0.05$ level in a one-tailed test.

\section{Conclusions}

Our results suggest several conclusions about the effect of trade on strikes in a labor-scarce country such as the United States. Overall, trade influences strikes but not primarily in a direct and simple way. First, we found little evidence that exposure to international trade directly reduces strike activity. Export orientation and import sensitivity were not robustly associated with the number of strikes or the number of person-days idle due to work stoppages. These results are consistent with arguments that both capital and labor can observe the effects of trade on their relative bargaining power and adjust their behavior accordingly. Trade might well affect the outcome of negotiations between them but not the probability that these negotiations will break down and result in a work stoppage.

Second, on the other hand, uncertainty arising from exposure to trade does have an effect on strike activity. The change in export orientation and import sensitivity, which produced our measure of uncertainty, was associated with more work stoppages and more person-days idle as a result. This effect stems from rapid change in the bargaining power of labor and capital. As Tsebelis and Lange have suggested, it is this uncertainty rather than bargaining power that makes strikes more likely. Both sides are more likely to miscalculate when conditions are changing, making a breakdown in the bargaining process and a work stoppage more likely.

Third, even though export orientation and import sensitivity had no direct effect on strike activity, import sensitivity could still affect union density and thus indirectly affect strike activity through this intervening variable. The evidence we reviewed suggests that increasing import sensitivity indeed diminished union density, a result that holds up whether one looks at the level of union density or the change in this variable. Because union density was strongly and positively associated with strike activity, import competition could indirectly reduce strike activity. As the immediate effect of import sensitivity on union density is small, this indirect effect is probably important mainly when increases in exposure to international trade are large and sustained over time. This has certainly been the case in the United States during the globalization of the past forty years.

These results suggest the broad outlines of the process through which exposure to international trade influences strike activity. Initially, the uncertainty created by rising exports and imports in a previously relatively closed economy produces more frequent work stoppages. However, the negative impact of import competition on union density reduces the frequency of strikes over time and eventually overwhelms the uncertainty effect of exposure to trade. Broadly speaking, this pattern reflects what took place in the United States during the postwar era.

Moving beyond our immediate findings, our results have some important (though tentative) implications about the political effects of international trade. The decline in union density is likely to be associated with a decline in the political power of organized labor. Because organized labor is one of the principal backers of the Democratic Party in the United States, and of left parties in other countries, expanding international trade seems likely to have strengthened the Republican Party in the United States and right parties in other relatively labor-scarce democracies. The progressive capture of U.S. state capitols by Republicans may be indicative of this process.

While this pattern is potentially important, it may not hold in countries with very different political and economic structures. For one thing, the United States is a relatively labor-scarce country. In a 
relatively labor-abundant economy, the export sector is likely to be more important in shaping the bargaining position of labor than is the import-competing sector, because the former will demand more labor than the latter. Other things being equal, trade liberalization should improve the bargaining position of labor in this setting and should also be associated with greater strike activity and perhaps stronger leftist parties.

Similarly, political features of the United States might also limit the importance of the patterns we found here in other national settings. The American labor movement is far weaker than the labor movement in many other states and is not linked to an explicitly labor or socialist party. In states where organized labor holds a stronger political position, it may be able to mitigate the effects of globalization on the labor market through government intervention.

Author Contributions: Both authors contributed equally to all parts of this paper. All authors have read and agreed to the published version of the manuscript.

Funding: This research received no external funding.

Conflicts of Interest: The authors declare no conflict of interest.

Appendix A

Table A1. Descriptive Statistics.

\begin{tabular}{ccccccc}
\hline & \multicolumn{3}{c}{ 1947-1981 } & \multicolumn{3}{c}{ 1984-2001 } \\
\hline & Mean & Min & Max & Mean & Min & Max \\
\hline $\begin{array}{c}\text { Work stoppages } \\
\text { Person-days idle due to work stoppages } \\
\text { (thousands) }\end{array}$ & 671 & 0 & 721 & 13.21 & 0 & 131 \\
\hline Manufacturing import sensitivity & 0.05 & 0.01 & 0.13 & 0.18 & 0.07 & 0.37 \\
\hline Manufacturing export orientation & 0.05 & 0.02 & 0.13 & 0.12 & 0.03 & 0.23 \\
\hline Uncertainty from exposure to trade & 0.17 & 0.01 & 1.54 & 0.12 & 0.002 & 0.54 \\
\hline Union density (percent of workforce) & 23.39 & 5.7 & 44.8 & 14.49 & 3.3 & 32.3 \\
\hline $\begin{array}{c}\text { Real per capita personal income } \\
\text { (thousands of US dollars) }\end{array}$ & 9.74 & 3.98 & 21.30 & 14.49 & 9.07 & 24.25 \\
\hline $\begin{array}{c}\text { Right-to-work law } \\
\text { Unemployment rate }\end{array}$ & 0.35 & 0 & 1 & 0.42 & 0 & 1 \\
\hline $\begin{array}{c}\text { Ideological orientation of state citizens } \\
\text { Ideological orientation of state } \\
\text { government }\end{array}$ & 44.47 & 1.8 & 14.6 & 5.55 & 2.26 & 14.72 \\
\hline Wage and salary employees (thousands) & 1.74 & 0.12 & 11.12 & 2.40 & 0.20 & 15.89 \\
\hline
\end{tabular}

\section{Appendix B}

Table A2. Alternative Models of Person-Days Lost to Work Stoppages in U.S. States.

\begin{tabular}{|c|c|c|c|c|}
\hline & \multicolumn{2}{|c|}{ Logged Dependent Variable } & \multicolumn{2}{|c|}{ Tobit Models of 1984-2001 Period } \\
\hline & 1964-1981 & 1984-2001 & $\begin{array}{l}\text { Dependent Variable } \\
\text { Not Logged }\end{array}$ & $\begin{array}{c}\text { Dependent } \\
\text { Variable Logged }\end{array}$ \\
\hline Manufacturing import sensitivity & $\begin{array}{l}-1.78 \\
(2.53)\end{array}$ & $\begin{array}{c}0.86 \\
(1.85)\end{array}$ & $\begin{array}{c}1602.46 \\
(1231.22)\end{array}$ & $\begin{array}{c}2.47 \\
(2.39)\end{array}$ \\
\hline Manufacturing export orientation & $\begin{array}{c}0.78 \\
(2.57)\end{array}$ & $\begin{array}{l}-5.60 \\
(2.95)\end{array}$ & $\begin{array}{l}-3342.13 \\
(1740.35)\end{array}$ & $\begin{array}{l}-11.95 \\
(3.38)\end{array}$ \\
\hline Uncertainty from exposure to trade & $\begin{array}{l}2.32 * \\
(0.56)\end{array}$ & $\begin{array}{c}0.21 \\
(0.84)\end{array}$ & $\begin{array}{c}463.41 \\
(489.43)\end{array}$ & $\begin{array}{c}0.58 \\
(0.89)\end{array}$ \\
\hline
\end{tabular}


Table A2. Cont.

\begin{tabular}{|c|c|c|c|c|}
\hline & \multicolumn{2}{|c|}{ Logged Dependent Variable } & \multicolumn{2}{|c|}{ Tobit Models of 1984-2001 Period } \\
\hline & 1964-1981 & 1984-2001 & $\begin{array}{l}\text { Dependent Variable } \\
\text { Not Logged }\end{array}$ & $\begin{array}{c}\text { Dependent } \\
\text { Variable Logged }\end{array}$ \\
\hline Union density (percent of workforce) & $\begin{array}{l}0.16^{*} \\
(0.02)\end{array}$ & $\begin{array}{l}0.34 * \\
(0.05)\end{array}$ & $\begin{array}{c}50.82 \\
(32.22)\end{array}$ & $\begin{array}{l}0.39 * \\
(0.06)\end{array}$ \\
\hline Union density squared & $\begin{array}{l}-0.002 * \\
(0.0003)\end{array}$ & $\begin{array}{l}-0.01 * \\
(0.001)\end{array}$ & $\begin{array}{l}-0.57 \\
(0.95)\end{array}$ & $\begin{array}{l}-0.01 * \\
(0.002)\end{array}$ \\
\hline $\begin{array}{l}\text { Real per capita personal income } \\
\text { (thousands of US dollars) }\end{array}$ & $\begin{array}{l}-0.06 * \\
(0.03)\end{array}$ & $\begin{array}{l}-0.09 * \\
(0.03)\end{array}$ & $\begin{array}{c}0.34 \\
(21.62)\end{array}$ & $\begin{array}{l}-0.09 * \\
(0.04)\end{array}$ \\
\hline Right-to-work law & $\begin{array}{l}-0.12 \\
(0.09)\end{array}$ & $\begin{array}{c}0.19 \\
(0.14)\end{array}$ & $\begin{array}{c}45.47 \\
(113.69)\end{array}$ & $\begin{array}{c}0.14 \\
(0.24)\end{array}$ \\
\hline Unemployment rate & $\begin{array}{c}0.01 \\
(0.02)\end{array}$ & $\begin{array}{l}-0.07 \\
(0.03)\end{array}$ & $\begin{array}{l}-25.96 \\
(22.99)\end{array}$ & $\begin{array}{l}-0.09 * \\
(0.04)\end{array}$ \\
\hline $\begin{array}{l}\text { Ideological orientation of state } \\
\text { citizens }\end{array}$ & $\begin{array}{c}-0.01 \\
(0.004)\end{array}$ & $\begin{array}{l}-0.002 \\
(0.004)\end{array}$ & $\begin{array}{l}-1.86 \\
(3.51)\end{array}$ & $\begin{array}{l}-0.002 \\
(0.007)\end{array}$ \\
\hline $\begin{array}{l}\text { Ideological orientation of state } \\
\text { government }\end{array}$ & $\begin{array}{l}0.0001 \\
(0.002)\end{array}$ & $\begin{array}{l}0.005 * \\
(0.002)\end{array}$ & $\begin{array}{c}0.40 \\
(1.70)\end{array}$ & $\begin{array}{l}0.008 * \\
(0.003)\end{array}$ \\
\hline $\begin{array}{l}\text { Wage and salary employees } \\
\text { (thousands) }\end{array}$ & & & $\begin{array}{l}0.09 * \\
(0.02)\end{array}$ & \\
\hline $\begin{array}{c}\text { Log of wage and salary employees } \\
\text { (thousands) }\end{array}$ & $\begin{array}{l}0.86 * \\
(0.08)\end{array}$ & $\begin{array}{l}1.02 * \\
(0.11)\end{array}$ & & $\begin{array}{l}1.26 * \\
(0.11)\end{array}$ \\
\hline Lagged dependent variable & $\begin{array}{l}0.28 * \\
(0.06)\end{array}$ & $\begin{array}{l}0.30 * \\
(0.07)\end{array}$ & $\begin{array}{l}-0.005 \\
(0.04)\end{array}$ & $\begin{array}{l}0.22 * \\
(0.04)\end{array}$ \\
\hline Constant & $\begin{array}{l}-3.58 * \\
(0.45)\end{array}$ & $\begin{array}{l}-6.43 * \\
(0.99)\end{array}$ & $\begin{array}{l}-459.36 \\
(461.39)\end{array}$ & $\begin{array}{l}-7.80 * \\
(1.06)\end{array}$ \\
\hline R-squared & 0.77 & 0.61 & & \\
\hline Observations & 876 & 849 & 849 & 849 \\
\hline
\end{tabular}

Note: The dependent variable is the annual number of person-days idle due to work stoppages, in thousands. Panel-corrected standard errors are reported in parentheses for the first two models. The tobit models treat the data as truncated at zero. Asterisks indicate statistical significance at the $p<0.05$ level in a one-tailed test.

\section{Discussion of Robustness Tests in Appendix B}

These robustness tests deal with two potential objections to our analysis. First, while the number of person-days idle is not an event count, it can never be less than zero. We log this variable because it has a positive skew. The first two models in the table above present such a specification, otherwise replicating the third set of models in Table 2 in the main text of the article. The results support the principal inferences drawn from the earlier results. Neither export orientation nor import sensitivity is statistically significant. As before, uncertainty predicts strike activity during the 1964-1981 period but not the 1984-2001 period. Among the control variables, only union density is significant in both periods.

A second potential objection to our results concerns the large number of instances during the 1984-2001 period when no strikes took place, and thus no person-days were lost. Of the 849 observations about person-days idle during this period in our dataset, 107 are zeroes. ${ }^{14}$ (This problem does not exist in the data for the 1947-1981 period because there is only one zero). The trouble is that the meaning of these "zero" observations is open to question. We observe zero person-days idle due to work stoppages both when strikes nearly took place and when strikes were considered impossible and never contemplated at all. From the standpoint of measuring "strike activity," these are different outcomes. Our dataset treats them as if they were the same. In more technical terms, the number of

14 This concern applies to the logged dependent variable as well. Because we added one to the number of person-days idle before logging it in order to avoid undefined values, there are an equal number of zeroes observed in those data. 
person-days lost to work stoppages is an observable indicator of a latent unobservable variable: the propensity of labor to strike. Strikes are only observed if this latent variable is above some threshold value. Observations that no strikes took place thus conflate cases in which the propensity to strike had very different values but fell below the threshold necessary to produce observable strike activity.

The tobit model was developed to deal with cases in which observations of an underlying latent variable are truncated in the observed data, as is the case here (Long 1997, pp. 187-216; Tobin 1958). The third and fourth models in Appendix C present tobit models of the number of person-days idle and the $\log$ of this variable. These models treat our dependent variable as a truncated indicator of an underlying propensity to strike that might be lower in some of these cases than others. This different interpretation of the number of person-days idle due to work stoppages suggests only small differences in our results. They support the same inferences drawn from the simpler models presented in Table 2 in the main text. During the 1984-2001 period, neither exposure to international trade nor labor market uncertainty caused by change in this condition was associated with strike activity.

\section{Appendix C}

Table A3. Models from Table 1 with Alternative Indicator of Trade-Related Uncertainty.

\begin{tabular}{|c|c|c|c|c|c|c|}
\hline & \multicolumn{2}{|c|}{ 1. No Controls } & \multicolumn{2}{|c|}{ 2. State Fixed Effects } & \multicolumn{2}{|c|}{ 3. Control Variables } \\
\hline & 1947-1981 & 1984-2001 & 1947-1981 & 1984-2001 & 1964-1981 & 1984-2001 \\
\hline $\begin{array}{l}\text { Manufacturing import } \\
\text { sensitivity }\end{array}$ & $\begin{array}{c}3.93 \\
(0.82)\end{array}$ & $\begin{array}{l}-4.28 * \\
(1.03)\end{array}$ & $\begin{array}{c}4.09 \\
(0.83)\end{array}$ & $\begin{array}{l}-3.76^{*} \\
(1.05)\end{array}$ & $\begin{array}{l}-4.70 * \\
(1.36)\end{array}$ & $\begin{array}{l}-4.18^{*} \\
(1.26)\end{array}$ \\
\hline $\begin{array}{c}\text { Manufacturing export } \\
\text { orientation }\end{array}$ & $\begin{array}{l}-7.72 \\
(1.04)\end{array}$ & $\begin{array}{l}-8.29 \\
(1.28)\end{array}$ & $\begin{array}{l}-7.81 \\
(1.05)\end{array}$ & $\begin{array}{l}-8.84 \\
(1.29)\end{array}$ & $\begin{array}{l}-6.58 \\
(1.31)\end{array}$ & $\begin{array}{l}-7.21 \\
(1.32)\end{array}$ \\
\hline $\begin{array}{l}\text { Uncertainty from } \\
\text { exposure to trade }\end{array}$ & $\begin{array}{l}11.31 * \\
(3.04)\end{array}$ & $\begin{array}{l}15.65^{*} \\
(4.11)\end{array}$ & $\begin{array}{l}11.34^{*} \\
(3.05)\end{array}$ & $\begin{array}{l}14.46^{*} \\
(4.20)\end{array}$ & $\begin{array}{l}26.29 * \\
(3.96)\end{array}$ & $\begin{array}{l}16.50 * \\
(4.14)\end{array}$ \\
\hline $\begin{array}{l}\text { Union density (percent } \\
\text { of workforce) }\end{array}$ & & & & & $\begin{array}{l}0.06^{*} \\
(0.02)\end{array}$ & $\begin{array}{l}0.10^{*} \\
(0.04)\end{array}$ \\
\hline Union density squared & & & & & $\begin{array}{l}-0.001 * \\
(0.0003)\end{array}$ & $\begin{array}{l}-0.002 * \\
(0.001)\end{array}$ \\
\hline $\begin{array}{c}\text { Real per capita personal } \\
\text { income (thousands of } \\
\text { US dollars) }\end{array}$ & & & & & $\begin{array}{c}0.06 \\
(0.02)\end{array}$ & $\begin{array}{l}-0.01 \\
(0.03)\end{array}$ \\
\hline Right-to-work law & & & & & $\begin{array}{l}-0.43^{*} \\
(0.11)\end{array}$ & $\begin{array}{l}-0.36 \\
(0.24) \\
\end{array}$ \\
\hline Unemployment rate & & & & & $\begin{array}{l}-0.05^{*} \\
(0.01)\end{array}$ & $\begin{array}{c}-0.04 * \\
(0.01)\end{array}$ \\
\hline $\begin{array}{l}\text { Ideological orientation } \\
\text { of state citizens }\end{array}$ & & & & & $\begin{array}{l}0.0004 \\
(0.002)\end{array}$ & $\begin{array}{l}-0.005 \\
(0.003)\end{array}$ \\
\hline $\begin{array}{l}\text { Ideological orientation } \\
\text { of state government }\end{array}$ & & & & & $\begin{array}{l}-0.001 \\
(0.001)\end{array}$ & $\begin{array}{c}0.001 \\
(0.001)\end{array}$ \\
\hline $\begin{array}{c}\text { Wage and salary } \\
\text { employees (thousands) }\end{array}$ & $\begin{array}{l}0.04 * \\
(0.02)\end{array}$ & $\begin{array}{l}0.15^{*} \\
(0.03)\end{array}$ & $\begin{array}{c}0.02 \\
(0.02)\end{array}$ & $\begin{array}{l}0.10^{*} \\
(0.03)\end{array}$ & $\begin{array}{c}0.02 \\
(0.02)\end{array}$ & $\begin{array}{l}0.14^{*} \\
(0.03)\end{array}$ \\
\hline $\begin{array}{l}\text { Lagged dependent } \\
\text { variable }\end{array}$ & $\begin{array}{c}0.002 * \\
(0.0001)\end{array}$ & $\begin{array}{l}0.004^{*} \\
(0.001)\end{array}$ & $\begin{array}{c}0.002 * \\
(0.0001)\end{array}$ & $\begin{array}{l}0.003 * \\
(0.001)\end{array}$ & $\begin{array}{l}0.002 * \\
(0.0001)\end{array}$ & $\begin{array}{l}0.004^{*} \\
(0.001)\end{array}$ \\
\hline Constant & $\begin{array}{l}2.49^{*} \\
(0.06)\end{array}$ & $\begin{array}{l}3.77^{*} \\
(0.21)\end{array}$ & $\begin{array}{l}2.52 * \\
(0.06)\end{array}$ & $\begin{array}{l}3.97^{*} \\
(0.22)\end{array}$ & $\begin{array}{l}2.34^{*} \\
(0.30)\end{array}$ & $\begin{array}{l}3.19^{*} \\
(0.59)\end{array}$ \\
\hline Observations & 1527 & 849 & 1527 & 849 & 876 & 849 \\
\hline
\end{tabular}

Note: The dependent variable is the annual number of work stoppages. Models estimated using time-series-cross sectional negative binomial model. Asterisks indicate statistical significance at the $p<0.05$ level in a one-tailed test. 
Table A4. Models from Table 2 with Alternative Indicator of Trade-Related Uncertainty.

\begin{tabular}{|c|c|c|c|c|c|c|}
\hline & \multicolumn{2}{|c|}{ 1. No Controls } & \multicolumn{2}{|c|}{ 2. State Fixed Effects } & \multicolumn{2}{|c|}{ 3. Control Variables } \\
\hline & 1947-1981 & 1984-2001 & 1947-1981 & 1984-2001 & 1964-1981 & 1984-2001 \\
\hline $\begin{array}{l}\text { Manufacturing import } \\
\text { sensitivity }\end{array}$ & $\begin{array}{l}-1510.49 \\
(2970.41)\end{array}$ & $\begin{array}{l}1050.82 \\
(708.90)\end{array}$ & $\begin{array}{c}7011.32 \\
(4922.67)\end{array}$ & $\begin{array}{c}2804.51 \\
(1257.97)\end{array}$ & $\begin{array}{l}-2550.61 \\
(2800.61)\end{array}$ & $\begin{array}{l}1325.83 \\
(743.19)\end{array}$ \\
\hline $\begin{array}{c}\text { Manufacturing export } \\
\text { orientation }\end{array}$ & $\begin{array}{l}-3916.31 \\
(2828.00)\end{array}$ & $\begin{array}{l}-2397.61 \\
(962.38)\end{array}$ & $\begin{array}{c}-14,250.21 \\
(4911.01)\end{array}$ & $\begin{array}{l}-4038.01 \\
(1443.00)\end{array}$ & $\begin{array}{l}-1773.93 \\
(2972.98)\end{array}$ & $\begin{array}{l}-1888.71 \\
(969.31)\end{array}$ \\
\hline $\begin{array}{l}\text { Uncertainty from } \\
\text { exposure to trade }\end{array}$ & $\begin{array}{l}28,960.76^{*} \\
(16,677.34)\end{array}$ & $\begin{array}{c}2715.51 \\
(4367.57)\end{array}$ & $\begin{array}{l}34,791.99 * \\
(16,372.63)\end{array}$ & $\begin{array}{c}1983.89 \\
(5150.77)\end{array}$ & $\begin{array}{l}40,927.68^{*} \\
(15,490.47)\end{array}$ & $\begin{array}{c}3190.06 \\
(4538.84)\end{array}$ \\
\hline $\begin{array}{l}\text { Union density (percent } \\
\text { of workforce) }\end{array}$ & & & & & $\begin{array}{c}16.87 \\
(21.14)\end{array}$ & $\begin{array}{l}-0.09 \\
(40.06)\end{array}$ \\
\hline Union density squared & & & & & $\begin{array}{c}0.35 \\
(0.49)\end{array}$ & $\begin{array}{c}0.87 \\
(1.55)\end{array}$ \\
\hline $\begin{array}{c}\text { Real per capita personal } \\
\text { income (thousands of } \\
\text { US dollars) }\end{array}$ & & & & & $\begin{array}{l}-45.96^{*} \\
(16.43)\end{array}$ & $\begin{array}{l}-1.11 \\
(9.80)\end{array}$ \\
\hline Right-to-work law & & & & & $\begin{array}{l}-121.32 * \\
(39.32)\end{array}$ & $\begin{array}{c}13.82 \\
(42.89)\end{array}$ \\
\hline Unemployment rate & & & & & $\begin{array}{l}-54.64 * \\
(25.77)\end{array}$ & $\begin{array}{l}-18.02 \\
(18.03)\end{array}$ \\
\hline $\begin{array}{l}\text { Ideological orientation } \\
\text { of state citizens }\end{array}$ & & & & & $\begin{array}{c}0.38 \\
(2.56)\end{array}$ & $\begin{array}{l}-0.74 \\
(1.34)\end{array}$ \\
\hline $\begin{array}{l}\text { Ideological orientation } \\
\text { of state government }\end{array}$ & & & & & $\begin{array}{l}-4.17 \\
(1.80)\end{array}$ & $\begin{array}{l}-1.15 \\
(1.02)\end{array}$ \\
\hline $\begin{array}{c}\text { Wage and salary } \\
\text { employees (thousands) }\end{array}$ & $\begin{array}{l}0.30 * \\
(0.04)\end{array}$ & $\begin{array}{l}0.07 * \\
(0.02)\end{array}$ & $\begin{array}{c}0.16 \\
(0.15)\end{array}$ & $\begin{array}{l}-0.02 \\
(0.11)\end{array}$ & $\begin{array}{l}0.26^{*} \\
(0.05)\end{array}$ & $\begin{array}{l}0.06^{*} \\
(0.02)\end{array}$ \\
\hline $\begin{array}{l}\text { Lagged dependent } \\
\text { variable }\end{array}$ & $\begin{array}{l}0.27^{*} \\
(0.10)\end{array}$ & $\begin{array}{c}0.07 \\
(0.19)\end{array}$ & $\begin{array}{c}0.01 \\
(0.10)\end{array}$ & $\begin{array}{l}-0.06 \\
(0.19)\end{array}$ & $\begin{array}{l}0.31 * \\
(0.11)\end{array}$ & $\begin{array}{c}0.03 \\
(0.19)\end{array}$ \\
\hline Constant & $\begin{array}{c}25.78 \\
(119.75)\end{array}$ & $\begin{array}{l}43.96 \\
(66.95)\end{array}$ & $\begin{array}{l}664.07^{*} \\
(208.13)\end{array}$ & $\begin{array}{c}241.41 \\
(196.96)\end{array}$ & $\begin{array}{c}268.88 \\
(326.63)\end{array}$ & $\begin{array}{c}-68.78 \\
(334.56)\end{array}$ \\
\hline R-squared & 0.47 & 0.07 & 0.58 & 0.18 & 0.62 & 0.10 \\
\hline Observations & 1525 & 849 & 1525 & 849 & 876 & 849 \\
\hline
\end{tabular}

Note: The dependent variable is the annual number person-days idle due to work stoppages, in thousands. Panel-corrected standard errors are reported in parentheses. Asterisks indicate statistical significance at the $p<0.05$ level in a one-tailed test.

\section{Discussion of Results in Appendix C}

As we noted in the main text, one potential objection to our treatment of trade-related uncertainty about the relative bargaining power of capital and labor is that it focuses only on change in our trade indicators within the most recent year. The indicator in the main text is the sum of the absolute change in the indicators of export orientation and import sensitivity. We believe this representation of trade-related uncertainty makes sense. Recent change should be a greater source of uncertainty because the actors have had less time to consider its impact on their bargaining position. However, a single year is an arbitrary choice; one could make a case for considering change over a longer period of time. The models in Tables A3 and A4 duplicate those from Tables 1 and 2 in the main text but use an indicator of uncertainty that considers change over the preceding five years. We constructed this by computing the standard deviation of each trade measure during this period and then summed these two statistics.

The results reported in Tables A3 and A4 have similar substantive implications to those in Tables 1 and 2 of the main text. As in Table 1, the results concerning the number of work stoppages in Table A3 indicate that uncertainty had roughly consistent effects in all three models. These effects were substantively larger during the 1947-1981 period when there were more work stoppages. A one standard deviation increase in the uncertainty variable was associated with an additional $4-5$ stoppages 
in model 1, 1 stoppage in model 2 and 15 stoppages in model 3 . These are slightly larger than the effects estimated for the one-year change in the trade variables.

As in Table 2, the effect of uncertainty on the number of days lost to work stoppages in Table A4 was less certain. The marginal effects for the 1947-1981 period were slightly larger than those obtained using the one-year change in the trade indices. A one standard deviation change in the five-year indicator was associated with 150,000-200,000 additional days lost to work stoppages. (This compares to 100,000-150,000 across the three models in Table 2). The larger effects for the five-year indicator in both models suggests that changes in exposure to trade over a longer period may have a cumulative effect on uncertainty greater than the one-year change. Nevertheless, the principal conclusion in the main text remains unchanged: there is empirical support for the trade-related uncertainty hypothesis.

\section{References}

Aronowitz, Stanley. 1973. False Promises: The Shaping of American Working Class Consciousness. New York: McGraw-Hill.

Ashenfelter, Orley, and George E. Johnson. 1969. Bargaining Theory, Trade Unions, and Industrial Strike Activity. American Economic Review 59: 35-49. Available online: https:/www.imf.org/external/pubs/ft/weo/2019/02/ weodata/index.aspx (accessed on 1 October 2020).

Beck, Nathaniel, and Jonathan N. Katz. 1995. What to do (and not to do) with Time-Series Cross-Section Data. American Political Science Review 89: 634-47. [CrossRef]

Berry, William, Evan Ringquist, Richard Fording, and Russell Hanson. 1998. Measuring Citizen and Government Ideology in the American States, 1960-1993. American Journal of Political Science 42: 327-48. [CrossRef]

Bhagwati, Jagdish N. 2004. In Defense of Globalization. New York: Oxford University Press.

Brady, D. 2007. Institutional, economic or solidaristic? Assessing explanations for unionizationacross affluent democracies. Work and Occupations 34: 67-101. [CrossRef]

Brecher, Jeremy. 1997. Strike! Cmbridge: South End Press.

Brueggemann, John, and Terry Boswell. 1998. Realizing Solidarity: Sources of Interracial Unionism during the Great Depression. Work and Occupations 25: 436-82. [CrossRef]

Card, David. 1988. Longitudinal Analysis of Strike Activity. Journal of Labor Economics 6: 147-76. [CrossRef]

Castells, Manuel. 1997. The Information Age. Oxford: Blackwell, vol. 2.

Cornfield, Daniel B. 1991. The U.S. Labor Movement: Its Development and Impact on Inequality and Politics. Annual Review of Sociology 17: 27-49. [CrossRef]

Cousineau, Jean-Michel, and Robert Lacroix. 1986. Imperfect Information and Strikes: An Analysis of Canadian Experience, 1967-1982. Industrial and Labor Relations Review 39: 377-87.

Dixon, Marc, Vincent J. Roscigno, and Randy Hodson. 2004. Unions, Solidarity, and Striking. Social Forces 83: 3-33. [CrossRef]

Dreher, Axel, and Noel Gaston. 2007. Has Globalisation Really had no Effect on Unions? Kyklos 60: 165-86. [CrossRef]

Dubofsky, Melvin, and Warren Van Tine. 1977. John Lewis: A Biography. Champaign: University of Illinois Press.

Edwards, Paul K. 1996. The Struggle for Control of the American Workplace, 1920-1985. In The Nature of Industrialization. Edited by Peter Mathies and John A. Davis. Oxford: Blackwell, pp. 150-203.

Ellis, Mark. 1992. The Determinants of Regional Differences in Strike in the U.S. 1971-1977. Annals of the Association of American Geographers 82: 48-63. [CrossRef]

Feenstra, Robert C. 1996. NBER Trade Database, Disk 1: U.S. Imports, 1972-1994: Data and Concordances. NBER Working Paper No. 5515. Cambridge: National Bureau of Economic Research, Inc.

Feenstra, Robert C., John Romalis, and Peter K Schott. 2002. U.S. Imports, Exports, and Tariff Data, 1989-2001. Davis: University of California at Davis, Unpublished Manuscript. Available online: http://cid.econ.ucdavis.edu/ pdf/nber_trade_data_2002.pdf (accessed on 3 May 2020).

Fordham, Benjamin O., and Timothy J. McKeown. 2003. Selection and Influence: Interest Groups and Congressional Voting on Trade Policy. International Organization 57: 519-49. [CrossRef]

Fording, Richard. 2020. State Ideology Data. Available online: https://rcfording.com/state-ideology-data/ (accessed on 16 October 2020). 
Franzosi, Roberto. 1989. One Hundred Years of Strike Statistics: Methodological and Theoretical Issues in Quantitative Strike Research. Industrial and Labor Relations Review 42: 348-62. [CrossRef]

Godard, John. 1992. Strikes as Collective Voice: A Behavioral Analysis of Strike Activity. Industrial and Labor Relations Review 46: 161-75. [CrossRef]

Gramm, Cynthia L. 1986. The Determinants of Strike Incidence and Severity: A Micro-Level Study. Industrial and Labor Relations Review 39: 361-76. [CrossRef]

Greenhouse, Steven. 2012. More Lockouts as Companies Battle Unions. New York Times, January 22, A1.

Hahnel, Robin. 2000. Globalization: Beyond Reaction, Thinking Ahead. New Politics. p. 8. Available online: http://www.wpunj.edu/ \{\}newpol/issue29/hahnel29.htm (accessed on 1 May 2020).

Hirsch, Barry T., David MacPherson, and Wayne G. Vrooman. 2001. Estimates of union density by State. Monthly Labor Review 124: 51-55. [CrossRef]

Hiscox, Michael J. 2002. International Trade and Political Conflict. Princeton: Princeton University Press.

International Monetary Fund. 2019. World Economic Outlook Database. Washington: International Monetary Fund, October.

Jenkins, J. Craig. 1983. Resource Mobilization Theory and the Study of Social Movements. Annual Review of Sociology 9: 527-53. [CrossRef]

Kaufman, Bruce E. 1981. Bargaining theory, inflation, and cyclical strike activity in manufacturing. Industrial and Labor Relations Review 34: 333-55. [CrossRef]

Kaufman, Bruce E. 1982. Determinants of Strikes in the United States 1900-1977. Industrial and Labor Relations Review 35: 473-90.

Kay, T. 2005. Labor transnationalism and global governance: The impact of NAFTA on transnational labor relationships in North America. American Journal of Sociology 111: 715-56. [CrossRef]

Kimeldorf, Howard. 1985. Working Class Culture, Occupational Recruitment, and Union Politics. Social Forces 64: 359-76. [CrossRef]

Kimeldorf, Howard. 1999. Battling for American Labor. Berkeley: University of California Press.

Levin, Andrew, Chien-Fu Lin, and Chia-Shang James Chu. 2002. Unit Root Tests in Panel Data: Asymptotic and Finite Sample Properties. Journal of Econometrics 108: 1-24. [CrossRef]

Long, J. Scott. 1997. Regression Models for Categorical and Limited Dependent Variables. Thousand Oaks: Sage Publications, Inc.

Mauro, Martin J. 1982. Strikes as a Result of Imperfect Information. Industrial and Labor Relations Review 35: 522-38. [CrossRef]

Mazur, Jay. 2000. Labor's New Internationalism. Foreign Affairs 79: 79-93. [CrossRef]

McCammon, Holly J. 1990. Legal Limits on Labor Militancy: U.S. Labor Law and the Right to Strike since the New Deal. Social Forces 37: 206-29.

McCammon, Holly J. 1993. From Repressive Intervention to Integrative Prevention: The U.S. State's Legal Management of Labor Militancy, 1881-1978. Social Forces 71: 569-601. [CrossRef]

McCammon, Holly J. 1994. Disorganizing and Reorganizing Conflict: Outcomes of the State's Legal Regulation of the Strike since the Wagner Act. Social Forces 72: 1011-49. [CrossRef]

Minkoff, Debra C. 1997. The Sequencing of Social Movements. American Sociological Review 62: 779-99. [CrossRef]

Mosley, Layna, and Saika Uno. 2007. Racing to the Bottom or Climbing to the Top? Economic Globalization and Labor Rights. Comparative Political Studies 40: 923-48. [CrossRef]

Neumayer, Eric, and Indra De Soysa. 2006. Globalization and the Right to Free Association and Collective Bargaining: An Empirical Analysis. World Development 34: 31-49. [CrossRef]

Peterson, Florence. 1938. Strikes in the United States, 1880-1936. Washington: U.S. Bureau of Labor Statistics.

Piazza, James A. 2005. Union Density and Strikes in 15 Industrialized Countries. Economic and Industrial Democracy 26: 289-314. [CrossRef]

Piven, Fracnes Fox, and Richard A. Cloward. 1979. Poor People's Movements: Why They Succeed, How They Fail. New York: Vintage Books.

Polanyi, Karl. 1957. The Great Transformation. Boston: Beacon Press.

Polletta, Francesca, and James Jasper. 2001. Collective Identity and Social Movements. Annual Review of Sociology 27: 283-305. [CrossRef]

Reddy, Sanjay, and Christian Barry. 2008. International Trade and Labor Standards. New York: Columbia University Press. 
Reder, Melvin W., and George R. Neumann. 1980. Conflict and Contract: The Case of Strikes. Journal of Political Economy 88: 867-86. [CrossRef]

Reed, W. Robert. 2003. How Right to Work Laws Affect Wages. Journal of Labor Research 24: 713-30. [CrossRef]

Reichert, Julia, Steven Bognar, Jeff Reichert, and Julie Parker Benello. 2019. American Factory. Edited by Julia Reichert and Steven Bognar. Los Gatos: Netflix.

Roscigno, Vincent J., and William Danaher. 2001. Media and Mobilization: The Case of Radio and Southern Textile Worker Insurgency, 1929-1934. American Sociological Review 66: 21-48. [CrossRef]

Rosenfeld, Jake. 2006. Desperate Measures: Strikes and Wages in Post-Accord America. Social Forces 85: $235-65$. [CrossRef]

Rubin, Beth A. 1986. Class Struggle American Style: Unions, Strikes, and Wages. American Sociological Review 51: 618-31. [CrossRef]

Scheve, Kenneth F., and Matthew J. Slaughter. 2001. What Determines Individual Trade-Policy Preferences? Journal of International Economics 54: 267-92. [CrossRef]

Schor, Juliet B., and Samuel Bowles. 1987. Employment Rents and the Incidence of Strikes. The Review of Economics and Statistics 69: 584-92. [CrossRef]

Scruggs, Lyle, and Peter Lange. 2002. Where have all the members gone? Globalization, institutions, and union density. Journal of Politics 64: 126-53. [CrossRef]

Shin, Gi-Wook. 1994. The Historical Making of Collective Action: The Korean Peasant Uprisings of 1946. American Journal of Sociology 99: 1596-624. [CrossRef]

Shorter, Edward, and Charles Tilly. 1974. Strikes in France, 1830-1968. Cambridge: Cambridge University Press.

Silver, Beverly J. 2003. Forces of Labor. Cambridge: Cambridge University Press.

Snyder, David. 1977. Early North American Strikes: A Reinterpretation. Industrial and Labor Relations Review 30: 325-41. [CrossRef]

Solidarity Center. 2007. Solidarity Center 2006-2007 Annual Report. Available online: http://www.solidaritycenter. org/files/pubs_2006_2007_annualreport.pdf (accessed on 10 August 2020).

Staudohar, Paul D. 2012. The basketball lockout of 2011. Monthly Labor Review, December 1, 28-33.

Stolper, Wolfgang F., and Paul A. Samuelson. 1941. Protection and Real Wages. Review of Economic Studies 9: 58-73. [CrossRef]

Taylor, Verta, and Nancy Whittier. 1992. Collective Identity in Social Movement Communities: Lesbian Feminist Mobilization. In Frontiers in Social Movement Theory. Edited by Aldon Morris and Carol McClurg. London: Yale University Press, pp. 104-29.

Tilly, Charles. 1995. Globalization Threatens Labor Rights. International Labor and Working Class History 47: 1-23. [CrossRef]

Tobin, James. 1958. Estimation of Relationships for Limited Dependent Variables. Econometrica 26: 24-36. [CrossRef]

Tonelson, Alan. 2002. The Race to the Bottom. New York: Westview Press.

Tsebelis, George, and Peter Lange. 1995. Strikes around the World: A Game Theoretic Approach. In The Workers of Nations. Edited by Sanford M. Jacoby. New York: Oxford University Press, pp. 101-25.

U.S. Bureau of Labor Statistics. 2019. Work Stoppages. Available online: https:/www.bls.gov/opub/hom/wsp/pdf/ wsp.pdf (accessed on 1 August 2020).

U.S. Department of Commerce, Bureau of Economic Analysis. 2008. Regional Economic Accounts. Available online: https://www.bea.gov/data/income-saving/personal-income-by-state (accessed on 1 August 2020).

U.S. Department of Labor. 2020. Bureau of Labor Statistics: Work Stoppages Frequently Asked Questions. Available online: https://www.bls.gov/wsp/questions-and-answers.htm (accessed on 18 August 2020).

United Nations. 2007. Corporate citizenship in the World Economy: The Global Compact Human Rights, Labor, Environment, Anti-Corruption. United Nations: Global Compact Office. Available online: http: //www.unglobalcompact.org/docs/about_the_gc/gc_brochure_final.pdf (accessed on 10 August 2020).

Van der Velden, Sjaak. 2006. Lockouts in the Netherlands: Why Statistics on Labour Disputes Must Discriminate Between Strikes and Lockouts, and Why New Statistics Need to Be Compiled. Historical Social Research 31: 341-62.

Vernby, Kåre. 2007. Strikes are more common in countries with majoritarian electoral systems. Public Choice 132: 65-84. [CrossRef]

Voss, Kim. 1993. The Making of American Exceptionalism. Ithaca: Cornell University Press. 
Walker, Richard A. 1999. Putting capital in its place: Globalization and the prospects for labor. Geoforum 30: $263-84$. [CrossRef]

Wallace, Michael, Larry J. Griffin, and Beth A. Rubin. 1989. The Positional Power of American Labor, $1963-1977$. American Sociological Review 54: 197-214. [CrossRef]

Walton, John, and Charles Ragin. 1990. Global and National Sources of Political Protest: Third World Responses to the Debt Crisis. American Sociological Review 60: 179-201. [CrossRef]

Wellman, David. 1995. The Union Makes Us Strong. Berkeley: University of California Press.

Winfree, Jason A. 2009. Owners incentives during the 2004-2005 National Hockey League lockout. Applied Economics 41: 3275-85. [CrossRef]

Woods, Ellen Meiksens, Peter Meiksens, and Michael Yates, eds. 1998. Rising from the Ashes? Labor in the Age of Global Capitalism. New York: Monthly Review Press.

Publisher's Note: MDPI stays neutral with regard to jurisdictional claims in published maps and institutional affiliations.

(C) 2020 by the authors. Licensee MDPI, Basel, Switzerland. This article is an open access article distributed under the terms and conditions of the Creative Commons Attribution (CC BY) license (http://creativecommons.org/licenses/by/4.0/). 